\title{
Identification of 2-Amino-1,7-dimethylimidazo[4,5-g]quinoxaline: An Abundant Mutagenic Heterocyclic Aromatic Amine Formed in Cooked Beef
}

\author{
Robert J. Turesky ${ }^{*}, \#$, Angela K. Goodenough", ${ }^{\text {, Weijuan Ni }}{ }^{\#}$, Lynn McNaughton§, David M.

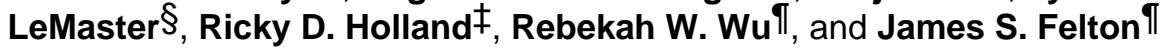 \\ \# Division of Environmental Disease Prevention, Wadsworth Center, New York State Department of Health, \\ Albany, NY 12201 \\ $\S$ Division of Molecular Medicine, Wadsworth Center, New York State Department of Health, Albany, NY \\ 12201 \\ $\$$ Division of System Toxicology, National Center for Toxicological Research, U.S. Food and Drug \\ Administration, Jefferson, AR 72079 \\ II Chemistry, Materials and Life Sciences Directorate, P.O. Box 808, Lawrence Livermore National, \\ Laboratory, Livermore, CA 94551
}

\section{Abstract}

A previously unknown isomer of the carcinogenic heterocyclic aromatic amine (HAA) 2-amino-3,8dimethylimidazo[4,5-f]quinoxaline (8-MeIQx) was recently discovered in urine of meat-eaters and subsequently detected in cooked ground beef [Holland, R.D. et al. (2004) Chem. Res. Toxicol. 17, 1121 - 1136]. In this current investigation, the identity of the analyte was determined through comparison of its chromatographic $t_{\mathrm{R}}$ by HPLC, and through UV and mass spectral comparisons to the synthesized isomers of 8-MeIQx. Angular tricyclic isomers of 8-MeIQx were excluded as potential structures of the newly discovered HAA, based upon dissimilar $t_{\mathrm{R}}$ and product ion mass spectral data. The linear tricyclic isomers 2-amino-1,6-dimethylimidazo[4,5-g]quinoxaline (6MeIgQx) and 2-amino-1,7-dimethylimidazo[4,5-g]quinoxaline (7-MeI $g \mathrm{Qx}$ ) were postulated as plausible structures. Both compounds were synthesized from 4-fluoro-5-nitro-benzene-1,2-diamine in five steps. The structure of the analyte was proven to be 7-MeIgQx, based upon co-injection of the compound with the synthetic isomers, and corroborated by comparisons of the UV and mass spectral data of the analyte and MeI $g$ Qx isomers. 7-MeI $g$ Qx induced 348 revertants $/ \mu$ g in the $S$. typhimurium tester strain YG1024, when liver S-9 homogenate of rats pretreated with polychlorinated biphenyls (PCBs) was used for bioactivation. This newly discovered 7-MeIgQx molecule is one of the most abundant HAAs formed in cooked ground beef patties and pan-fried scrapings. The human health risk of 7-MeIgQx requires investigation.

\section{Introduction}

More than 20 HAAs have been identified in cooked beef, poultry, and fish, as well as in tobacco smoke condensate $(1,2)$. The formation of HAAs is dependent upon the type of meat and method of cooking, and the concentrations can range from less than 1 part-per-billion (ppb),

*To whom correspondence should be addressed: Division of Environmental Disease and Prevention, Wadsworth Center, NYS Dept of Health, Empire State Plaza, P.O. Box 509, Albany, NY 12201-0509. Phone: 518-474-4151. Fax: 518-486-1505. E-mail:

rturesky@wadsworth.org.

†Formerly Angela K. Brock 
up to $500 \mathrm{ppb}$ in meats or poultry that are cooked well-done (2). Many HAAs are potent bacterial mutagens and induce tumors in multiple tissues of experimental laboratory animals during long-term feeding studies (1). The frequent consumption of red meats has been reported to be associated with an elevated risk of colon cancer in humans (3). Moreover, a markedly increased risk of colorectal cancer has been observed among individuals who frequently consume meats that are cooked well-done and who are both rapid cytochrome P450 1A2mediated $N$-oxidizers and rapid $N$-acetylators $(4,5)$; both of these phenotypes are associated with enzymes capable of bioactivating HAAs. Several studies have reported the detection of HAA-DNA adducts in human tissues, even though the concentrations of HAAs in the diet are generally at the low ppb level (6-9). Thus, some of the epidemiological data reported on frequent meat consumption, putative HAA exposure, and genetic polymorphisms in xenobiotic enzymes implicate HAAs as causal risk factors for human cancers.

The mechanisms of formation and biochemical toxicology of HAAs have been studied for more than 20 years. Much of the research has been devoted to 8-MeIQx and 2-amino-1methyl-6-phenylimidazo[4,5-b]pyridine (PhIP), since these compounds are two of the most abundant HAAs formed in cooked meats. It is noteworthy that the known HAAs only account for about $30 \%$ of the total mutagenicity attributed to HAAs in well-done cooked beef (10), suggesting that other uncharacterized, genotoxic HAAs are likely present. We recently discovered, by LC/MS analysis, a previously unknown isomer of 8-MeIQx in urine of meateaters (11), and we subsequently identified the compound in grilled meats $(11,12)$. In this investigation, we have isolated the novel HAA from pan-fried scrapings of cooked beef, and have characterized the molecule by UV and MS. The spectral data were compared to those of several synthesized angular and linear tricylic isomers of 8-MeIQx. The spectral data support the assigned structure of the molecule as 7-MeIgQx. This newly identified HAA is one of the most abundant HAAs formed in cooked ground beef and pan-fried scrapings.

\section{Materials and Methods}

\section{Caution}

HAAs are carcinogenic. They should be handled in a well-ventilated hood with extreme care, and with use of appropriate protective clothing and equipment.

\section{Chemicals}

The following chemicals were purchased from Toronto Research Chemicals (Downsview, Ontario, Canada): 2-amino-3-methylimidazo[4,5-f]quinoline (IQ) and trideuterated 3- $\left[{ }^{2} \mathrm{H}_{3} \mathrm{C}\right]-$ IQ (isotopic purity >99\%), 2-amino-1-methylimidazo[4,5-b]quinoline (IQ[4,5-b]), 2-amino-3methylimidazo[4,5-f]quinoxaline (IQx), 2-amino-3,8-dimethylimidazo[4,5-f]quinoxaline (8MeIQx) and the trideuterated 3-[ $\left.{ }^{2} \mathrm{H}_{3} \mathrm{C}\right]-8$-MeIQx (isotopic purity >96\%), 2-amino-3,7dimethylimidazo[4,5-f]quinoxaline (7-MeIQx), 2-amino-1-methyl-6-phenylimidazo[4,5-b] pyridine (PhIP) and trideutrated 1- $\left[{ }^{2} \mathrm{H}_{3} \mathrm{C}\right]-\mathrm{PhIP}$ (isotopic purity >99\%), 2-amino- $9 \mathrm{H}$-pyrido [2,3-b] indole $(\mathrm{A} \alpha \mathrm{C}), 2$-amino-3-methyl-9H-pyrido[2,3-b]indole (MeA $\alpha \mathrm{C})$. 2-Amino-3,4,8trimethylimidazo[4,5-f]quinoxaline (4,8-DiMeIQx), 2-amino-3,7,8-trimethylimidazo[4,5-f] quinoxaline (7,8-DiMeIQx), 3-[ $\left.{ }^{2} \mathrm{H}_{3} \mathrm{C}\right]-4,8$-DiMeIQx and 3-[ $\left.{ }^{2} \mathrm{H}_{3} \mathrm{C}\right]-7,8-\mathrm{DiMeIQx}$ (isotopic purity $>99 \%$ ) were synthesized as previously described (13). 1-[ $\left[{ }^{2} \mathrm{H}_{3} \mathrm{C}\right]-\mathrm{IQ}[4,5-\mathrm{b}]$ (isotopic purity $>99 \%$ ) was synthesized from $1-\left[{ }^{2} \mathrm{H}_{3} \mathrm{C}\right]$-creatinine and 2-aminobenzaldehyde (14), and 2-amino-1,8-dimethylimidazo[4,5-f]quinoxaline was synthesized as previously described (11). $\left[4 b, 5,6,7,8,8 b-{ }^{13} \mathrm{C}_{6}\right]-2-\mathrm{A} \alpha \mathrm{C}$ (isotopic purity >99\%) was a kind gift of Dr. D. Doerge, Jefferson, NCTR, AR. 2-Amino-3,4-dimethylimidazo[4,5-f]quinoxaline (4-MeIQx) was kindly provided by Dr. M. Knize, Lawrence Livermore National Laboratory, Livermore, CA. 2-Amino-1,7,9-trimethylimidazo[4,5-g]quinoxaline (7,9-DiMeI $g \mathrm{Qx}$ ) was kindly provided by Dr. K. Wakabayashi, National Cancer Center Research Institute, Tokyo, Japan. CNBr, 
pyruvaldehyde (40\%), hydrazine hydrate (50\% v/v), and palladium/carbon (10\%) were purchased from Sigma-Aldrich (Milwaukee, WI). 4-Fluoro-5-nitro-benzene-1,2-diamine was purchased from Maybridge through Ryan Scientific Inc. (Isle of Palms, SC). Oasis MCX LP extraction $(500 \mathrm{mg})$ and borosilicate glass total recovery capLC vials were purchased from Waters (Milford, MA). Extrelut-20 resin was obtained from EMD Chemicals (Gibbs Town, $\mathrm{NJ}$ ). $\mathrm{C}_{18}$ solid phase extraction (SPE) resins (500 or $1000 \mathrm{mg}$ ) werer purchased from J.T. Baker (Phillipsburg, NJ) and glass-back TLC plates were purchased from Whatman (Florham Park, $\mathrm{NJ})$.

\section{General Methods}

Mass spectra of synthetic derivatives were obtained on a Finnigan ${ }^{\mathrm{TM}}$ TSQ Quantum Ultra ${ }^{\mathrm{TM}}$ triple quadrupole (TSQ) mass spectrometer (Thermo Electron, San Jose, CA). Typical instrument tune parameters used were as follows: capillary temperature $275^{\circ} \mathrm{C}$, source spray voltage $4.0 \mathrm{kV}$, sheath gas setting 35 , tube lens offset 95 , capillary offset 35 , source fragmentation $15 \mathrm{~V}$. Argon, set at $1.5 \mathrm{mTorr}$, was used as the collision gas. Analyses were conducted in positive ionization mode. NMR spectra were collected on a Bruker $600 \mathrm{MHz}$ DRX Spectrometer (Bruker BioSpin Corporation, Billerica, MA) using solutions in $\mathrm{CDCl}_{3}$ or DMSO- $d_{6}$. Selected NMR spectra are provided in the Supplementary Information. HPLC separations were done with an Agilent (Palo Alto, CA) model 1100 HPLC system equipped with a photo-diode array detector equipped with a Rheodyne 7725i (Rhonert Park, CA) manual injector

\section{Syntheses}

$\boldsymbol{N}^{4}$-Methyl-5-nitro-benzene-1,2,4-triamine (2)-A mixture of 4-fluoro-5-nitrobenzene-1,2-diamine (1) (50 mg, $0.29 \mathrm{mmol})$, methylamine- $\mathrm{HCl}$ (194 mg, $2.9 \mathrm{mmol})$, and anhydrous sodium acetate $(237 \mathrm{mg}, 2.9 \mathrm{mmol})$ in anhydrous DMSO $(10 \mathrm{~mL})$ was stirred at $120{ }^{\circ} \mathrm{C}$ for $4 \mathrm{~h}$. After cooling, water $(125 \mathrm{~mL})$ was added and the mixture was applied to a Baker $\mathrm{C}_{18}$ SPE resin $(1 \mathrm{~g})$, prewashed with $\mathrm{CH}_{3} \mathrm{OH}$ and then water. After the application of the sample, the cartridge was washed with water, and the desired product was eluted with 10 bed volumes of $\mathrm{CH}_{3} \mathrm{OH}$, which was evaporated under vacuum to give $2(48 \mathrm{mg}, 0.26 \mathrm{mmol}$, 90\%). ${ }^{1} \mathrm{H}$ NMR (DMSO- $d_{6}$ ): $\delta 8.43\left(\mathrm{~d}, J=4.8 \mathrm{~Hz}, 1 \mathrm{H}, N^{4}-\mathrm{H}\right.$ ), 7.18 (s, $\left.1 \mathrm{H}, \mathrm{H}-6\right), 6.47$ (2H, 2$\left.\mathrm{NH}_{2}\right), 5.83(1 \mathrm{H}, \mathrm{H}-3), 4.52\left(2 \mathrm{H}, 1-\mathrm{NH}_{2}\right), 2.85\left(\mathrm{~d}, J=5.0 \mathrm{~Hz}, 3 \mathrm{H}, N 4-\mathrm{CH}_{3}\right)$. Positive ESI-MS (relative intensity) $\mathrm{m} / \mathrm{z} 183.0[\mathrm{M}+\mathrm{H}]^{+}$, MS/MS of $183.0(100 \%), 166.1(20 \%), 148.0(35 \%)$, $137.0(25 \%)$.

N,3-Dimethyl-7-nitro-quinoxalin-6-amine (3a)-A solution of 2 (40 mg, $0.22 \mathrm{mmol}$ ) and methylglyoxal $(17.3 \mathrm{mg}, 0.24 \mathrm{mmol})$ in $1: 1 \mathrm{H}_{2} \mathrm{O}: \mathrm{C}_{2} \mathrm{H}_{5} \mathrm{OH}(10 \mathrm{~mL})$ was heated at $50{ }^{\circ} \mathrm{C}$ for $1 \mathrm{~h}$. The mixture was placed under a stream of argon to evaporate the $\mathrm{C}_{2} \mathrm{H}_{5} \mathrm{OH}$, and the desired product, which precipitated from solution, was collected by centrifugation, washed with cold water, and dried under vacuum to give $3 \mathrm{a}(38 \mathrm{mg}, 0.18 \mathrm{mmol}, 82 \%) .{ }^{1} \mathrm{H}$ NMR $\left(\mathrm{CDCl}_{3}\right): \delta 8.93(1 \mathrm{H}, 8-\mathrm{H}), 8.53(1 \mathrm{H}, \mathrm{H}-2), 7.58(\mathrm{br}, \mathrm{H}, N 6-\mathrm{H}), 7.17(1 \mathrm{H}, \mathrm{H}-5), 3.15(\mathrm{~d}, J=$ $\left.5.2 \mathrm{~Hz}, 3 \mathrm{H}, \mathrm{N6}-\mathrm{CH}_{3}\right), 2.73\left(3 \mathrm{H}, 3-\mathrm{CH}_{3}\right) .{ }^{13} \mathrm{C} \mathrm{NMR}\left(\mathrm{CDCl}_{3}\right): 168.147(\mathrm{C} 3), 146.184(\mathrm{C} 4 \mathrm{a})$, 144.855 (C6), 144.627 (C2), 136.062 (C7), 131.789 (C8a), 129.098 (C8), $110.229\left(\mathrm{N6}_{-} \mathrm{CH}_{3}\right)$, 107.472 (C5), $103.131\left(3-\mathrm{CH}_{3}\right)$. Positive ESI-MS (relative intensity) $\mathrm{m} / 2.219 .1[\mathrm{M}+\mathrm{H}]^{+}$, MS/ MS of 219.1 (60\%), 189.0 (10\%), 173.1 (90\%), 144.1 (100\%).

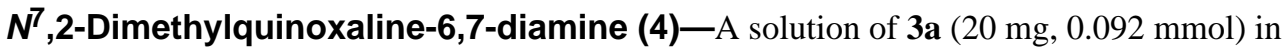
anhydrous THF ( $3 \mathrm{~mL}$ ) was reduced with $\mathrm{H}_{2}$ at atmospheric pressure using $\mathrm{Pd} / \mathrm{C}(5 \mathrm{mg})$ as a catalyst. After $4 \mathrm{~h}$, the $\mathrm{Pd} / \mathrm{C}$ was removed by centrifugation, the charcoal was washed with $\mathrm{C}_{2} \mathrm{H}_{5} \mathrm{OH}(2 \times 1 \mathrm{~mL})$, and the pooled organic extracts were dried under vacuum to give 4 (14 $\mathrm{mg}, 0.074 \mathrm{mmol}, 82 \%)$. Due to the instability of compound $\mathbf{4}$, the product was characterized by LC-ESI-MS/MS only and used without further purification. Positive ESI-MS (relative 
intensity) $\mathrm{m} / z 189.2[\mathrm{M}+\mathrm{H}]^{+}, \mathrm{MS} / \mathrm{MS}$ of $189.2(45 \%), 174.1(100 \%), 157.8(5 \%), 147.1$ $(35 \%)$.

2-Amino-1,7-dimethylimidazo[4,5-g]quinoxaline (5a)—Compound 4 (14 mg, 0.074 mmol) was treated with $\mathrm{CNBr}(11 \mathrm{mg}, 0.10 \mathrm{mmol})$ in $\mathrm{C}_{2} \mathrm{H}_{5} \mathrm{OH}(2 \mathrm{~mL})$ under argon for $18 \mathrm{~h}$ at room temperature. Concentrated $\mathrm{NH}_{4} \mathrm{OH}(26 \% \mathrm{v} / \mathrm{v})(0.1 \mathrm{~mL})$ was added and the mixture was dried under vacuum. The crude residue was purified by preparative silica TLC (20\% $\left.\mathrm{CH}_{3} \mathrm{OH}, 0.2 \% \mathrm{NH}_{4} \mathrm{OH}, 79.8 \% \mathrm{CH}_{2} \mathrm{Cl}_{2}\right)$ to give $5 \mathbf{a}(0.5 \mathrm{mg}, 0.002 \mathrm{mmol}, 3 \%) .{ }^{1} \mathrm{H} \mathrm{NMR}$ (DMSO- $\left.d_{6}\right): \delta 8.58(\mathrm{~s}, 1 \mathrm{H}, \mathrm{H}-6), 7.58(\mathrm{~s}, 1 \mathrm{H}, \mathrm{H}-9), 7.55(\mathrm{~s}, 1 \mathrm{H}, \mathrm{H}-4), 7.20\left(\mathrm{br}, 2 \mathrm{H}, \mathrm{NH}_{2}\right), 3.61$ (s, 3H, N1- $\mathrm{CH}_{3}$ ), $2.63\left(\mathrm{~s}, 3 \mathrm{H}, 7-\mathrm{CH}_{3}\right) .{ }^{13} \mathrm{C}$ NMR (DMSO- $\left.d_{6}\right)$ : $\delta 159.073(\mathrm{C} 2), 148.523(\mathrm{C} 7)$, 145.887 (C3a), 141.844 (C6), 139.207 (C9a), 137.098 (C4a), 136.658 (C8a), 118.29 (N1$\left.\mathrm{CH}_{3}\right), 111.259\left(7-\mathrm{CH}_{3}\right), 108.886(\mathrm{C} 4), 101.767(\mathrm{C} 9)$. Positive ESI-MS (relative intensity) $\mathrm{m} /$ $z 214[\mathrm{M}+\mathrm{H}]^{+}, \mathrm{MS} / \mathrm{MS}$ of $214.1(15 \%), 199.1(100 \%), 172.2(20 \%), 130.9(75 \%)$.

5-Fluoro-6-nitro-1 H-benzimidazole-2-amine (6)-A solution of compound 1 (100 mg, $0.58 \mathrm{mmol})$ in $\mathrm{C}_{2} \mathrm{H}_{5} \mathrm{OH}(5 \mathrm{~mL})$ was reacted with $\mathrm{CNBr}(184 \mathrm{mg}, 1.74 \mathrm{mmol})$ under argon for $18 \mathrm{~h}$. Concentrated $\mathrm{NH}_{4} \mathrm{OH}(26 \% \mathrm{v} / \mathrm{v})(0.5 \mathrm{~mL})$ was added, and the mixture was dried under vacuum. The residue was resolubilized with warm water, allowed to precipitate on ice, collected by filtration, and then dried by rotary evaporation, to give compound $\mathbf{6}(100 \mathrm{mg}, 0.51$ mmol, 88\%). ${ }^{1} \mathrm{H}$ NMR (DMSO- $\left.d_{6}\right): \delta 7.87(\mathrm{~d}, J=6.9 \mathrm{~Hz}, 1 \mathrm{H}, 7-\mathrm{H}), 7.28(\mathrm{br}, 3 \mathrm{H}, N \mathrm{H}-1$ and 2- $\mathrm{NH}_{2}$ ), 7.15 (d, $J=12.8 \mathrm{~Hz}, 1 \mathrm{H}, \mathrm{H}-4$ ). Positive ESI-MS (relative intensity) $\mathrm{m} / z .197 .1[\mathrm{M}+$ $\mathrm{H}]^{+}, \mathrm{MS} / \mathrm{MS}$ of $197.1(5 \%), 151.0(100 \%), 124.1$ (185), $97.1(5 \%)$.

6-Nitro-1 H-benzoimidazole-2,5-diamine (7)—A solution of compound 6 (50 mg, 0.26 mmol) in DMSO $(3.5 \mathrm{~mL})$ and concentrated $\mathrm{NH}_{4} \mathrm{OH}(26 \%)(1.25 \mathrm{~mL})$ was heated at $130{ }^{\circ} \mathrm{C}$ for 5 days. After cooling, the reaction mixture was diluted with water $(100 \mathrm{~mL})$ and applied to a Baker $\mathrm{C}_{18} \mathrm{SPE}$ resin $(1 \mathrm{~g})$, prewashed with $\mathrm{CH}_{3} \mathrm{OH}$, followed by water. Following application of the sample, the cartridge was washed with water, and the product was eluted with $\mathrm{CH}_{3} \mathrm{OH}$ $(10 \mathrm{~mL})$. The $\mathrm{CH}_{3} \mathrm{OH}$ was evaporated under vacuum and the resulting residue was purified by preparative silica TLC $\left(20 \% \mathrm{CH}_{3} \mathrm{OH}\right.$ in $\mathrm{CH}_{2} \mathrm{Cl}_{2}$ containing $0.2 \% \mathrm{NH}_{4} \mathrm{OH}$,) to give 7 (40 mg, $0.2 \mathrm{mmol}, 78 \%$ ). ${ }^{1} \mathrm{H}$ NMR (DMSO- $d_{6}$ ): $\delta 7.68(\mathrm{br}, 1 \mathrm{H}, \mathrm{NH}-1), 7.08$ (s, $\left.1 \mathrm{H}, \mathrm{H}-7\right), 6.95$ (br, 2H, 2- $\mathrm{NH}_{2}$ ), $6.51(\mathrm{~s}, 1 \mathrm{H}, \mathrm{H}-4)$. Positive ESI-MS (relative intensity) $\mathrm{m} / z .194[\mathrm{M}+\mathrm{H}]^{+}$, MS/MS of 194.1 (10\%), $164.0(5 \%), 148.0$ (100\%), 121.0 (35\%).

1H-Benzimidazole-2,5,6-triamine (8)-A solution of compound 7 (10 mg, $0.052 \mathrm{mmol}$ ) in $\mathrm{CH}_{3} \mathrm{OH}(1 \mathrm{~mL})$ was treated with $\mathrm{NaBH}_{4}(4 \mathrm{mg}, 0.11 \mathrm{mmol})$ in water $(1 \mathrm{~mL})$ that was premixed with $5 \mathrm{mg} \mathrm{Pd} / \mathrm{C}$ in $\mathrm{CH}_{3} \mathrm{OH}(1 \mathrm{~mL})$ for $15 \mathrm{~min}$ at room temperature (15). Then, the $\mathrm{Pd} / \mathrm{C}$ was removed by centrifugation and the charcoal was washed with $\mathrm{C}_{2} \mathrm{H}_{5} \mathrm{OH}(2 \times 1 \mathrm{~mL})$. The excess $\mathrm{NaBH}_{4}$ in the combined organic extracts was inactivated by the drop-wise addition of $20 \%$ acetic acid $(1 \mathrm{~mL})$. The LC-ESI-MS analysis of the reaction by infusion in full scan mode revealed that the reduction of 7 was complete. Positive ESI-MS (relative intensity) $\mathrm{m} / \mathrm{z}$ $164.0[\mathrm{M}+\mathrm{H}]^{+}, \mathrm{MS} / \mathrm{MS}$ of $164.0(15 \%), 147.1(100 \%), 120.1(90 \%)$. Due to instability of the reduced diamine compound $\mathbf{8}$, the product was characterized by LC/ESI-MS only and used without further purification.

2-Amino-6-methyl-1 H-imidazo[4,5-g]quinoxaline (Compound 9)-The solution of the diamine 8 ( $8 \mathrm{mg}, 0.05 \mathrm{mmol})$ was immediately reacted with methylglyoxal $(4.3 \mathrm{mg}, 0.06$ $\mathrm{mmol}$ ) and heated at $50{ }^{\circ} \mathrm{C}$ for $15 \mathrm{~min}$. After cooling, the mixture was diluted with water (50 $\mathrm{mL}$ ) and applied to a Baker $\mathrm{C}_{18}$ solid phase extraction cartridge $(1 \mathrm{~g})$, prewashed with $\mathrm{CH}_{3} \mathrm{OH}$ and then by water. Following application of the sample, the cartridge was washed with water, and product was eluted with $\mathrm{CH}_{3} \mathrm{OH}(10 \mathrm{~mL})$. The eluent was evaporated under vacuum to give 9 ( $8.5 \mathrm{mg}, 0.04 \mathrm{mmol}, 80 \%) .{ }^{1} \mathrm{H}$ NMR (DMSO- $\left.d_{6}\right): \delta 8.58(\mathrm{~s}, 1 \mathrm{H}, \mathrm{H}-7), 7.58(\mathrm{br}, 1 \mathrm{H}$, 
NH-1), 7.50 (br, 2H, NH 2 ), 6.98 (s, 2H, H-9, H-4), 2.65 (s, 3H, 6- $\mathrm{CH}_{3}$ ). Positive ESI-MS (relative intensity) $\mathrm{m} / \mathrm{z} 200.1[\mathrm{M}+\mathrm{H}]^{+}$, MS/MS of $200.1(50 \%), 173.2(45 \%), 159.1(20 \%)$, $132.3(100 \%)$.

2-Amino-1,7-dimethyl-1 $\mathrm{H}$-imidazo[4,5-g]quinoxaline (Compound 5a) and 2amino-1,6-dimethyl-1 $\mathrm{H}$-imidazo[4,5-g]quinoxaline (Compound $5 \mathrm{~b}$ ) $-\mathrm{CH}_{3} \mathrm{I}$ (30 $\mu \mathrm{mol})$ was added to a mixture of compound $9(5 \mathrm{mg}, 25 \mu \mathrm{mol})$ and $\mathrm{K}_{2} \mathrm{CO}_{3}(4 \mathrm{mg}, 30 \mu \mathrm{mol})$ in anhydrous DMSO $(0.5 \mathrm{~mL})(16)$. The reaction mixture was stirred for $2 \mathrm{~h}$ at room temperature to produce 2-amino-1,7-dimethylimidazo[4,5-g]quinoxaline (7-MeIgQx) (5a) and 2amino-1,6-dimethylimidazo[4,5-g]quinoxaline (6-MeIgQx) (5b) in $\sim 1: 1$ ratio, based upon HPLC, using System 1 (vide infra). Following purification by HPLC and evaporation of solvent under high vacuum, compounds $\mathbf{5 a}$ and compound $\mathbf{5 b}$ were recovered $(2.4 \mathrm{mg}$ of each compound; $11 \mu \mathrm{mol} ; 44 \%$ yield per compound). The NMR and LC-ESI-MS/MS spectral data of 7-MeIgQx (5a) were identical to those data acquired on the molecule synthesized by reaction of compound 4 with $\mathrm{CNBr}$ (vide supra). 6- MeIgQx (5b) $\left.{ }^{1} \mathrm{H} \mathrm{NMR} \mathrm{(DMSO-} d_{6}\right): \delta 8.56(\mathrm{~s}, 1 \mathrm{H}$, $\mathrm{H}-7), 7.61$ (s, $1 \mathrm{H}, \mathrm{H}-9), 7.50$ (s, 1H, H-4), $7.35\left(\mathrm{br}, 2 \mathrm{H}, \mathrm{NH}_{2}\right), 3.62\left(3 \mathrm{H}, N 1-\mathrm{CH}_{3}\right), 2.63(3 \mathrm{H}$, 6- $\mathrm{CH}_{3}$ ). ${ }^{13} \mathrm{C}$ NMR (DMSO- $d_{6}$ ): $\delta 160.089(\mathrm{C} 2), 150.077$ (C6), 147.616 (C3a), 141.991 (C7),

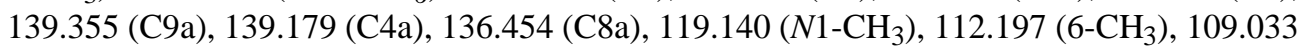
(C4), 103.233 (C9). Positive ESI-MS (relative intensity) $\mathrm{m} / z 214[\mathrm{M}+\mathrm{H}]^{+}, \mathrm{MS} / \mathrm{MS}$ of 214.1 (15\%), 199.1 (100\%), 172.2 (20\%), 130.9 (75\%).

\section{Tandem Solvent-Solid Phase Extraction (SPE) of HAAs from Cooked Meat}

Grilled meat samples or pan-fried scrapings ( $4 \mathrm{~g}$ ) were spiked with isotopically labeled HAAs (4 $\mathrm{ng}$ for meat and $40 \mathrm{ng}$ for pan-fried scrapings), homogenized in $1 \mathrm{~N} \mathrm{NaOH}(15 \mathrm{~mL})$, mixed thoroughly with Extrelut-20 powder (18 g), and placed into a cartridge holder as previously described (17), except that an MCX cartridge, instead of independent $C_{18}$ and sulfonic acid SPE resins, was used for simultaneous collection of both apolar and polar HAAs (12). The eluents from the MCX cartidge were concentrated by vacuum centrifugation, resuspended in $0.1 \% \mathrm{HCO}_{2} \mathrm{H}(30 \mu \mathrm{L})$, and assayed by HPLC-ESI-MS or further purified by HPLC as described below.

\section{HPLC conditions for purification of synthetic MelgQx isomers and cooked meat mutagens}

System 1-HPLC separation of MeIgQx isomers, on a Waters XBridge ${ }^{\mathrm{TM}}$ phenyl column (5 $\mu \mathrm{m}$ particle size; $4.6 \times 250 \mathrm{~mm})$. The A buffer was $15 \mathrm{mM}$ ammonium acetate $(\mathrm{pH} 6.8)$ and the $\mathrm{B}$ solvent was $\mathrm{CH}_{3} \mathrm{CN}$. A linear gradient was employed, starting at $8 \% \mathrm{CH}_{3} \mathrm{CN}$ and arriviing at $12 \% \mathrm{CH}_{3} \mathrm{CN}$ over $60 \mathrm{~min}$ at a flow rate of $1 \mathrm{~mL} / \mathrm{min}$.

System 2-HAAs in grilled pan scrapings (4 g, not spiked with isotopically labeled internal standards), were partially purified by tandem SPE and further purified by HPLC using an Aquasil $\mathrm{C}_{18}$ reversed-phase column $(4.5 \times 250 \mathrm{~mm} ; 5 \mu \mathrm{m}$ particle size $)$ and Javelin precolumn, Thermo Electron Corp. (Bellefonte, PA). The A buffer was $0.1 \% \mathrm{HCO}_{2} \mathrm{H}$ and the B solvent was $\mathrm{CH}_{3} \mathrm{CN}$. The meat components were separated by means of a linear gradient starting at $100 \% \mathrm{~A}$ and ending at $100 \% \mathrm{~B}$, over $60 \mathrm{~min}$, at a flow rate of $1 \mathrm{~mL} / \mathrm{min}$. One-minute fractions were collected and infused by LC-ESI-MS/MS (vide infra), to identify the fractions that contained 7-MeIgQx and 8-MeIQx.

System 3-Further HPLC purification of HAAs in cooked meats was done with the same Aquasil $\mathrm{C}_{18}$ reversed-phase column and Javelin precolumn, and employed the same gradient and flow conditions of System 2, except that solvent A consisted of $50 \mathrm{mM}$ ammonium acetate (pH 6.8) containing $10 \% \mathrm{CH}_{3} \mathrm{CN}$. 
System 4-Analyses of HAAs in cooked meat by LC-ESI-MS/MS. Chromatography was performed on an Agilent Technologies 1100 series capillary LC system. The separation of HAAs was done with an Aquasil $\mathrm{C}_{18}$ reversed-phase column $(1 \times 250 \mathrm{~mm}, 5 \mu \mathrm{m}$ particle size $)$ and Javelin precolumn. The flow rate was set at $50 \mu \mathrm{L} / \mathrm{min}$ with a linear gradient over $30 \mathrm{~min}$, starting from $100 \%$ solvent $\mathrm{A}\left(0.1 \% \mathrm{HCO}_{2} \mathrm{H}\right.$ containing $\left.0.5 \% \mathrm{CH}_{3} \mathrm{CN}\right)$ and ending at $100 \%$ solvent B (90\% $\left.\mathrm{CH}_{3} \mathrm{CN}: 9.9 \% \mathrm{H}_{2} \mathrm{O}: 0.1 \% \mathrm{HCO}_{2} \mathrm{H}\right)$.

\section{LC-ESI-MS/MS Analyses}

The MS analyses were done by ESI-MS/MS with either the TSQ MS or a Waters/Micromass Quattro Ultima triple quadrupole MS (Manchester, UK). Quantitative analysis was done in positive ionization mode using the SRM transitions $[\mathrm{M}+\mathrm{H}]^{+}>[\mathrm{M}+\mathrm{H}-15]^{+\bullet}\left(\operatorname{loss}\right.$ of $\left.\mathrm{CH}_{3}{ }^{\circ}\right)$ for IQ, IQ[4,5-b], IQx, 8-MeIQx, 4,8-DiMeIQx, 7,9-DiMeIgQx, and PhIP, and $[\mathrm{M}+\mathrm{H}]^{+}>[\mathrm{M}+\mathrm{H}$ $-18]^{+}$(loss of $\mathrm{CD}_{3}{ }^{\circ}$ ), for the respective trideuterated internal standards (12,18-20). For $\mathrm{A} \alpha \mathrm{C}$, $\mathrm{MeA} \alpha \mathrm{C}$, and 2-[ $\left.{ }^{13} \mathrm{C}_{6}\right]-\mathrm{A} \alpha \mathrm{C}$, the SRM transition was $[\mathrm{M}+\mathrm{H}]^{+}>[\mathrm{M}+\mathrm{H}-44]^{+}$, which is attributed to the loss of $\mathrm{NH}_{3}$, followed by loss of $\mathrm{HCN}$. The dwell time for each transition was set at $0.1 \mathrm{~s}$. Individual instrument parameters were optimized by infusion the HAAs with a syringe pump into the MS source through a mixing tee, at a flow rate of $10 \mu \mathrm{L} / \mathrm{min}$, with the LC solvent $(1: 1 \mathrm{~A}: \mathrm{B})\left(\mathrm{A}=0.1 \% \mathrm{HCO}_{2} \mathrm{H}\right.$ containing $\left.0.5 \% \mathrm{CH}_{3} \mathrm{CN}\right)$ and $\mathrm{B}=90 \% \mathrm{CH}_{3} \mathrm{CN}$ : $9.9 \% \mathrm{H}_{2} \mathrm{O}: 0.1 \% \mathrm{HCO}_{2} \mathrm{H}$ ) flowing at $50 \mu \mathrm{L} / \mathrm{min}$. The optimized instrument tune parameters for the TSQ MS were those conditions described in General Methods (vide supra).

For the Waters/Micromass Quattro Ultima triple quadrupole MS, the capillary voltage was set at $3.5 \mathrm{kV}$, the cone voltage was set at $50 \mathrm{~V}$, hexapoles 1 and 2 were set at 18 and $1 \mathrm{~V}$, respectively. The collision energy was optimized for each HAA with values between 29 and $32 \mathrm{eV}$. The source and desolvation temperatures were 120 and $350{ }^{\circ} \mathrm{C}$, respectively. The $\mathrm{N}_{2}$ cone gas flow rate was set at $95 \mathrm{~L} / \mathrm{h}$, and the desolvation gas flow rate was $500 \mathrm{~L} / \mathrm{h}$. Argon, set at a pressure of $2.5 \mathrm{mTorr}$, was used as the collision gas. The LC solvent conditions were the same as those described above. Product ion spectra of the analytes were obtained on the protonated molecules $[\mathrm{M}+\mathrm{H}]^{+}$scanning from $\mathrm{m} / \mathrm{z} 100$ to 250 at a scan speed of $150 \mathrm{Da} / \mathrm{s}$, using the same acquisition parameters described above for the two instruments.

Quantitation of HAAs was done with an external calibration curve, injecting $266 \mathrm{pg}$ of internal standards $(2 \mu \mathrm{L})$ containing unlabeled HAAs at nine calibrant levels ranging from 2.66 to 4,000 $\mathrm{pg}$ injected on column, or the equivalent of 0.01 to $15 \mathrm{ppb}$ of HAA in cooked meat. Since isotopically labeled internal standards were not available for IQx, 7,9-DiMeIgQx, and MeA $\alpha$ C, the $3-\left[{ }^{2} \mathrm{H}_{3} \mathrm{C}\right]-8$-MeIQx, $1-\left[{ }^{2} \mathrm{H}_{3} \mathrm{C}\right]-\mathrm{PhIP}$, and $\left[{ }^{13} \mathrm{C}_{6}\right]-\mathrm{A} \alpha \mathrm{C}$ were used as the respective internal standards. The coefficient of determination $\left(r^{2}\right)$ of all HAA calibration curves exceeded 0.998 .

\section{Bacterial Mutagenesis Assays}

The genotoxicity of HAAs was conducted in the Ames reversion assay, which measures revertants that are protrophic and functional in histidine biosynthesis (21). Both tester strains Salmonella typhimurium TA98 or YG1024 $\left(0.1 \mathrm{ml}, 1 \times 10^{9} \mathrm{cells} / \mathrm{ml}\right)$ were employed. The Standard Pour Plate method (21) in which the test chemical, bacteria and metabolic activating enzymes ( $\mathrm{S}-9$ mix) were added directly to the top agar without preincubation. After mixing, the entire content was poured onto the minimal glucose agar Petri plates. The plates were then incubated for $48 \mathrm{~h}$ at $37^{\circ} \mathrm{C}$. To construct a dose response curve, the cells were exposed to nontoxic concentrations of HAAs, and the revertant colonies were quantified as previously reported (22). The activating enzymes (S-9 mix) consisted of cofactors: NADP (4 mM), glucose-6-phosphate $(5 \mathrm{mM}), \mathrm{MgCl}_{2}(8 \mathrm{mM}), \mathrm{KCl}(33 \mathrm{mM})$, sodium phosphate buffer (100 $\mathrm{mM}$ at $\mathrm{pH} 7.4$ ), and the $\mathrm{S}-9$ fraction of rat liver homogenate ( $2 \mathrm{mg}$ of protein concentration per plate). To prepare the S-9 fraction, six-week-old male Sprague Dawley rats were used. They 
were injected with a single dose of Aroclor 1254 at $500 \mathrm{mg} / \mathrm{kg}$ body weight. Five days later, the rats were euthanized and the liver were removed for processing (the procedure was approved by the Institute of Animal Care and Utilization Committee (IACUC)) at the Lawrence Livermore National Laboratory).

\section{Results}

\section{Identification of Known HAAs and Detection of Novel HAAs in Cooked Meat by LC-ESI-MS}

The chemical structures of many HAAs formed in cooked meat, including those HAAs investigated in this study are depicted in Figure 1. The LC-ESI-MS/MS analyses of HAAs formed in ground beef patties pan-fried at $\sim 165^{\circ} \mathrm{C}$ for $10 \mathrm{~min} /$ side are presented in Figure 2. 8-MeIQx is the most abundant of the known HAAs formed in ground beef cooked at $165^{\circ} \mathrm{C}$, followed by 4,8-DiMeIQx, IQx, and PhIP. Lesser amounts of 7,9-DiMeIgQx were also detected, along with trace amounts of IQ, its linear tricyclic isomer, IQ[4,5- $b$ ], and the pyrolysis mutagens, $\mathrm{A} \alpha \mathrm{C}$ and $\mathrm{MeA} \alpha \mathrm{C}(11,12)$. These HAAs were also detected in the scrapings of the pan-fried ground beef (12). The extracts of both fried meat samples and pan-fried scrapings were analyzed by LC-ESI-MS/MS in the product ion scan mode, which provided characteristic mass fragmentations of the protonated molecules $[\mathrm{M}+\mathrm{H}]^{+}$, for corroboration of the analytes' identities (MS data shown in references $(12,19))$

In addition to these known compounds, five other putative HAAs were detected and labeled as peaks a -e (Figure 2). These analytes underwent ESI-MS/MS fragmentation to produce products ions attributed to the IQx skeleton (12). One prominent analyte, peak b, was identified as an isomer of 8-MeIQx $(11,12)$. The spectroscopic characterization of this compound is described below. The identities of the other putative HAAs, putative isomers of IQx (peak a) and DiMeIQx (peaks c, d, and e) remain to be determined.

The protonated molecule $[\mathrm{M}+\mathrm{H}]^{+}$of peak b and that of 8-MeIQx occur at $m / z 214$, and the two compounds undergo the same MS/MS transition $\left([\mathrm{M}+\mathrm{H}]^{+}>[\mathrm{M}+\mathrm{H}-15]^{+\bullet}\right.$ (due to loss of $\left.\mathrm{CH}_{3}{ }^{\circ}\right)$ ). The product ion spectra of peak b and 8-MeIQx are presented in Figure 3. The spectra are similar: many of the same fragment ions are observed, although with differing relative abundances. The accurate mass measurement of peak $b$ in full scan and product ion scan modes by ESI-quadruople-time-of-flight-MS proved that the molecule was an isomer of 8-MeIQx (11). The angular tricyclic isomers 4-MeIQx, 7-MeIQx, and the N1-methyl-isomer of 8-MeIQx were excluded as plausible structures of the analyte, based upon $t_{\mathrm{R}}$ values and product ion spectra that differed from those of the analyte in grilled meat (data not shown) (11). The exclusion of these molecules suggested that a linear tricyclic ring compound was a plausible structure of the isomer.

The similarities in the product ion mass spectra of peak $\mathrm{b}$ and 8-MeIQx provided insight into the structure of the isomer. The proposed mechanisms of mass fragmentation of 8-MeIQx are based upon isotopically unlabeled compound, and labeled 3-[ $\left.{ }^{2} \mathrm{H}_{3} \mathrm{C}\right]-8-\mathrm{MeIQx}$ and $2-\left[{ }^{14} \mathrm{C}\right]-8-$ MeIQx derivatives (19). The initial, principal cleavage of 8-MeIQx occurs at the $N 3-\mathrm{CH}_{3}$ bond, to produce the radical cation species at $m / z 199\left[\mathrm{M}+\mathrm{H}-\mathrm{CH}_{3}{ }^{\circ}\right]^{+}$, which subsequently undergoes cleavage of the pyrazine ring to produce fragment ions at $\mathrm{m} / z .172\left[\mathrm{M}+\mathrm{H}-\mathrm{CH}_{3}{ }^{\circ}\right.$ $-\mathrm{HCN}]^{+}, m / z 158\left[\mathrm{M}+\mathrm{H}-\mathrm{CH}_{3}{ }^{\circ}-\mathrm{CH}_{3} \mathrm{CN}\right]^{+}$, and $m / z 131\left[\mathrm{M}+\mathrm{H}-\mathrm{CH}_{3}{ }^{-}-\mathrm{HCN}-\right.$ $\left.\mathrm{CH}_{3} \mathrm{CN}\right]^{+}(19)$. The product ion spectrum of the labeled 2-[ $\left.{ }^{14} \mathrm{C}\right]-8$-MeIQx analogue displayed the same pattern of fragmentation, but the product ions were up-shifted by $2 \mathrm{Da}$, proving that the ${ }^{14} \mathrm{C}$-labeled imidazole moiety remains intact under these LC-ESI-MS/MS conditions (19). The product ion spectrum of the novel analyte is simlar to the spectrum of 8-MeIQx, except that the fragment ion at $m / z 131$ is more abundant, suggesting that the analyte contains an $N$-methylimidazo[4,5-g]quinoxaline ring system and not an $N$-methylimidazole[4,5-b] 
quinoxaline skeleton; the latter ring structure would not be expected to undergo fragmentation to produce the fragment ion at $\mathrm{m} / \mathrm{z}, 131$ as the base peak in the spectrum.

\section{Syntheses of 6-MelgQx and 7-MelgQx}

The syntheses of 6-MeIgQx and 7-MeIgQx were undertaken to determine whether either compound was the novel analyte formed in cooked beef. The chemical syntheses are described in Schemes 1 and 2. The ${ }^{1} \mathrm{H}$ NMR spectra, and HMBC and ROESY experiments for many of the key synthetic intermediates are presented in the Supplementary Information. The stereoselective synthesis of 7-MeIgQx (Scheme 1) was done in five steps starting from commercially available 4-fluoro-5-nitro-benzene-1,2-diamine. The key intermediate was $\mathrm{N}^{4}$ methyl-5-nitro-benzene-1,2,4-triamine (2). The electron-withdrawing, para-directed effect of the nitro substituent resulted in the selective reaction of the meta $1-\mathrm{NH}_{2}$ group of compound 2 with the aldehydic carbon of methyglyoxal, to form N,3-dimethyl-7-nitro-quinoxalin-6amine (3a) (23). Based upon ${ }^{1} \mathrm{H}$ NMR, there was no evidence for the formation of the isomeric N,2-dimethyl-7-nitro-quinoxalin-6-amine (3b) (Supporting Information, Figure 1). The position of the newly formed $\mathrm{CH}_{3}$-group on the pyrazine portion of the quinoxaline ring of compound 3a was determined through HMBC experiments (Supporting Information, Figure 2). A long-range correlation was observed between the $\mathrm{C} 4 \mathrm{a}$ carbon and $\mathrm{H}-8$. If the compound 3b isomer had formed, an additional correlation between $\mathrm{C} 4 \mathrm{a}$ and $\mathrm{H}-3$ would have been expected. $\mathrm{H}-2$ displays only one long-range correlation to $\mathrm{C} 8 \mathrm{a}$, and establishes that $\mathrm{H}-2$ and H-8 are on the same edge of the ring system.

The final ring-closure step of the diamine 4a with CNBr produced 7-MeIgQx (5a) (Supporting Information, Figure 3). The through space ROEs corroborated that the 7- $\mathrm{CH}_{3}$ and $\mathrm{N}-\mathrm{CH}_{3}$ groups were on the same edge of the molecule: ROEs were observed between the $\mathrm{N1}-\mathrm{CH}_{3}$ and the H-9 (peak-to-peak S/N 40) and between the 7- $\mathrm{CH}_{3}$ and the $\mathrm{H}-9$ (peak-to-peak $\mathrm{S} / \mathrm{N} \sim 10$ ) (Supporting Information, Figures 4 and 5). There were no ROEs observed between either $\mathrm{CH}_{3}$ group and the $\mathrm{H}-4$. Long-range through-bond couplings, in the HMBC experiments, were observed from H-6 to C4a, from H-9 to C4a, and from H-4 to C8a and C9a (Supporting Information, Figure 6).

However, compound 5a was obtained in only several percent yield and numerous unwanted products were formed. We investigated different reaction conditions, by usage of alternative solvents and temperatures, in attempts to improve the efficiency of the CNBr-ring-closure step, but we attained no appreciable increase in the yield of 5a. The use of activated di(imidazole-1yl)methanimine (24) or S-methyl(isothiourea) (25) derivatives as cyclo condensing reagents, instead of $\mathrm{CNBr}$, also resulted in poor yields of compound 5a. Low product yields have similarly been reported for the CNBr-ring-closure step of the diamine precursors of PhIP (26) and several other HAAs (25).

Because of the low yields of 7-MeIgQx by Scheme 1, we devised an alternative scheme for the synthesis of both isomers (Scheme 2). 4-Fluoro-5-nitro-benzene-1,2-diamine was reacted with $\mathrm{CNBr}$ to produce 5-fluoro-6-nitro- $1 H$-benzimidazole-2-yl amine (6) in near-quantitative yield. The ring closure with $\mathrm{CNBr}$ also served as a protective group for the $o$-diamines, which undergo oxidation during the direct amination of compound $\mathbf{1}$ with concentrated $\mathrm{NH}_{4} \mathrm{OH}$ (R.T., unpublished observations). Following amination of compound $\mathbf{6}$, reduction of the nitro moiety was achieved with $\mathrm{NaBH}_{4}$, with $\mathrm{Pd} / \mathrm{C}$ used as a catalyst (15). The resultant diamine 7, was condensed with methylglyoxal to produce compound $\mathbf{8}$ at high yield. The treatment of compound $\mathbf{8}$ with $\mathrm{CH}_{3} \mathrm{I}$ resulted in formation of 6-MeIgQx (5b) and 7-MeIgQx (5a) in a 1:1 ratio, based upon ${ }^{1} \mathrm{H}$ NMR analysis (data not shown).

The 6-MeIgQx and 7-MeIgQx isomers were not resolved by either silica TLC or by $\mathrm{C}_{8}$ or $\mathrm{C}_{18}$ reversed-phase HPLC, using a variety of different solvents, buffers, and $\mathrm{pH}$ conditions. 
However, baseline resolution of the two isomers was achieved by HPLC, using a Waters XBridge ${ }^{\text {TM }}$ Phenyl column (HPLC System I). The ${ }^{1} \mathrm{H}$ NMR spectrum of 6-MeIgQx is shown in Supporting Information, Figure 7. The positions of the $\mathrm{CH}_{3}$ groups on the 6-MeIgQx molecule were determined primarily through space ROESY NMR experiments (Supporting Information, Figures 8 and 9), which showed ROEs between 6- $\mathrm{CH}_{3}$ and $\mathrm{H}-7$ (peak-to-peak S/ $\mathrm{N} \sim 60$ ) and to a lesser extent between the 6- $\mathrm{CH}_{3}$ and $\mathrm{H}-4$ (peak to peak $\mathrm{S} / \mathrm{N} \sim 10$ ). An ROE was also observed between the $N 1-\mathrm{CH}_{3}$ to the $\mathrm{H}-9$ (peak-to-peak $\mathrm{S} / \mathrm{N} \sim 50$ ); however, no ROE was observed between 6- $\mathrm{CH}_{3}$ to $\mathrm{H}-9$. $\mathrm{HMBC}$ experiements revealed long-range coupling between H-7 to C8a, H-4 to C8a, and between H-9 to C4a and C3a (Supporting Information, Figure 10). These three-bond couplings were more intense than the corresponding two-bond couplings and had intensities of $\sim 50$ for peak to peak S/N. Hence, H-9 and H-7 are on the same edge of the molecule, and the two $\mathrm{CH}_{3}$ groups are on opposite edges of the molecule.

\section{Comparisons of Chromatographic $\left(t_{\mathrm{R}}\right)$ and UV and LC-ESI-MS/MS Spectra of the Analyte in Grilled Meat and Synthetic 6-MelgQx and 7-MelgQx Isomers}

Kilogram quantities of grilled meat or pan-scrapings would be required for us to obtain the MeIgQx isomer (peak b, Figure 2) in quantities sufficient to conduct structural characterization by NMR spectroscopy. Therefore, in order to establish the identity of the positional MeIgQx isomer in cooked meat, we compared the online-UV and LC-ESI-MS/MS mass spectral data for the analyte to those for the synthetic MeI $g$ Qx isomers. The LC/MS chromatogram of panfried meat scrapings, unspiked, synthetic 6-MeIgQx and 7-MeIgQx standards, and meatscrapings spiked with MeI $g$ Qx isomers monitored in the full product ion scan mode, are shown in Figures 4 A-C. In the unspiked pan-fried meat scrapings, there are two peaks with protonated molecules $[\mathrm{M}+\mathrm{H}]^{+}$at $m / z 214.1$. The isomer of 8-MeIQx elutes at a $t_{\mathrm{R}} 41.3 \mathrm{~min}$, while 8-MeIQx elutes at a $t_{\mathrm{R}} 44.1 \mathrm{~min}$. The pan-fried meat scrapings was spiked with comparable amounts of the synthetic 6-MeIgQx and 7-MeIgQx isomers. 7-MeIgQx was found to co-elute with the analyte in cooked meat at $t_{\mathrm{R}} 41.3 \mathrm{~min}$, while 6-MeIgQx eluted at $t_{\mathrm{R}} 42.6 \mathrm{~min}$. The use of the characteristic $t_{\mathrm{R}}$ as a means of identification of the analyte was crucial for identification purposes, since the product ion spectra of the analyte and of the synthetic 6- and 7-MeIgQx isomers are identical (data not shown).

UV spectroscopy was used to corroborate the identity of the analyte as 7-MeIgQx. The UV spectra of synthetic 6-MeIgQx and 7-MeIgQx, and of the analyte in pan-fried meat scrapings, acquired online by HPLC, are shown in Figure 4D. The UV spectra of the synthetic 6- and 7MeI $g$ Qx compounds are very similar; however, subtle differences are discernible in the absorbance maxima centered about 255 and $360 \mathrm{~nm}$ for both the two molecules. There is a $\sim 3-\mathrm{nm}$ bathochromic shift in the maximum of 6-MeIgQx relative to 7-MeIgQx (363 vs. 360 $\mathrm{nm}$ ), and the second maximum at $255 \mathrm{~nm}$ in the spectrum of 6-MeIgQx is less intense than the maximum observed for 7-MeIgQx. The UV spectrum of the analyte purified from the panfried scrapings of beef is a perfect match to the spectrum of 7-MeIgQx. The UV spectra of synthetic 8-MeIQx and the 8-MeIQx analyte isolated from cooked beef, shown in Figure 4B, differ notably from the spectra of the linear MeI $g$ Qx isomers. Thus, on the basis of cochromatography experiments and UV spectroscopy, the structure of the novel 8-MeIQx isomer in grilled meat was proven to be 7-MeIgQx.

\section{LC/ESI-MS Product Ion Spectra of 7-MelgQx and 7,9-DiMelgQx}

7,9-DiMeI $g \mathrm{Qx}$ was previously identified, at low concentrations, in cooked beef extract (27) and fried ground beef (12). At the outset of our investigation, 6- and 7-MeIgQx were dismissed as plausible structures for the analyte, because their mass fragmentations were vastly different from that of the dimethylated 7,9-DiMeI $g$ Qx homologue, under the ESI-MS/MS conditions employed. 7,9-DiMeI $g \mathrm{Qx}$ is a stable molecule and undergoes little fragmentation, while the pyrazine ring of 7-MeIgQx readily undergoes cleavage (Figure 5). Prominent fragment ions 
of 7,9-DiMeIgQx [M $+\mathrm{H}]^{+}(\mathrm{m} / z$ 228) are observed at $\mathrm{m} / z, 213$ and 212 and are respectively attributed to $\left[\mathrm{M}+\mathrm{H}-\mathrm{CH}_{3}{ }^{\circ}\right]^{+}$and $\left[\mathrm{M}+\mathrm{H}-\mathrm{CH}_{4}\right]^{+}$. We attribute the loss of $\mathrm{CH}_{4}$ to abstraction of a $\mathrm{H}^{\bullet}$ from the $9-\mathrm{CH}_{3}$, which is epi to the $N 1-\mathrm{CH}_{3}$ group $(11,20)$ (Scheme 3). The resulting product ion at $m / z, 212\left[\mathrm{M}+\mathrm{H}-\mathrm{CH}_{4}\right]^{+}$is a stable 2-amino-6-methyl-4-methyleneimidazo[4,5$g$ ]quinoxaline/2-amino-4,6-dimethylimidazo[4,5-g]quinoxalin-2-amine cationic species; this fragment ion is the base peak in the product ion spectrum of 7,9-DiMeIgQx even at high CID energy conditions. 7-MeIgQx $[\mathrm{M}+\mathrm{H}]^{+}(\mathrm{m} / z, 214)$ also undergoes fragmentation at the $N 1-$ $\mathrm{CH}_{3}$ bond to form a radical cation species at $m / 2199\left[\mathrm{M}+\mathrm{H}-\mathrm{CH}_{3}{ }^{\circ}\right]^{+}$; however, the $7-\mathrm{CH}_{3}$ group of 7-MeIgQx is not in close proximity to the $N 1-\mathrm{CH}_{3}$ group and is thus unable to donate a $\mathrm{H}^{*}$ to produce $\mathrm{CH}_{4}$ as a neutral fragment. Therefore, secondary fragmentation occurs at the pyrazine ring to produce the 2-amino-benozimidazole radical cation species $(\mathrm{m} / \mathrm{z}, 131[\mathrm{M}+\mathrm{H}$ $\left.-\mathrm{C}_{4} \mathrm{H}_{7} \mathrm{~N}_{2}\right]^{+}$) as the base peak in the product ion spectrum.

\section{Estimates of 7-MelgQx and other HAAs in Fried Beef}

The concentration of 7-MeIgQx and other known HAAs formed in ground beef patties fried at various temperatures were quantitated; the results are depicted in Figure 6 A - C. 7-

MeIgQx and 8-MeIQx are the two most abundant HAAs formed during the cooking of ground beef patties at a pan-frying temperature of $\sim 165^{\circ} \mathrm{C}$ for $10 \mathrm{~min}$ per side, and 7-MeIgQx is the most abundant of all the HAAs recovered in the pan-fried meat scrapings after $10 \mathrm{~min}$ of cooking (Figure 6B) 7-MeIgQx and PhIP are formed in the maximal amounts in ground beef patties prepared at higher cooking temperatures (Figure 6C).

\section{Bacterial Mutagenicity of PhIP, 8-MelQx Isomers, and 7,9-DiMelgQx}

The Ames reversion assay with tester strains TA98 and YG1024 was conducted to assess the genotoxic potencies of HAAs, with liver S-9 fraction of rats pretreated with PCBs used for bioactivation. The YG1024 strain is derived from strain TA98 (hisD3052, $\Delta u v r B, r f a$, pKM101) and contains high $O$-acetyltransferase (OAT) activity that enhances the mutagenicity of some HAAs, presumably through the formation of the reactive $\mathrm{N}$-acetoxy intermediates, which adduct to DNA $(28,29)$. The estimated mutagenic potencies of 8-MeIQx, 6-MeIgQx, 7MeIgQx, 7,9-DiMeIgQx, and PhIP in TA98 and YG1024 tester strains are summarized in Table 1. The dose-response curves of the mutagenicity are shown in Supporting Information, Figure 11. 8-MeIQx is potent in both tester strains and induces mutations at $<1 \mathrm{ng}$ per plate. All of the other HAAs assayed are weaker in potency than 8-MeIQx by a factor of $\geq 100$-fold in both tester strains. All of the putative $N$-hydroxy-HAA metabolites were substrates for OAT and were more potent mutagens in tester strain YG1024 than in strain TA98. 7-MeIgQx elicited the highest differential fold induction of revertants in YG1024 over tester strain TA98.

\section{Discussion}

Even though HAAs have been monitored in cooked meats for more than 20 years $(1,30,31)$, our studies are the first to report the formation of 7-MeIgQx in cooked ground beef. 7$\mathrm{MeI} g \mathrm{Qx}$ is one of the most mass-abundant HAAs formed in ground beef patties cooked over a wide range of temperatures $\left(165-300^{\circ} \mathrm{C}\right)$. Early investigations that sought to identify HAAs in cooked meat employed multiple chromatography steps, and the mutagens were monitored, by the Ames bacterial mutagenesis assay, at each step of the purification $(1,30,32)$. The purified mutagenic fractions were characterized by ${ }^{1} \mathrm{H}-\mathrm{NMR}$ and MS for structural elucidation. These methods were extremely labor-intensive, and kg quantities of grilled meat were required to produce amounts of HAAs sufficient for spectroscopic measurements $(30,32)$. Since the mutagenic potencies of HAAs vary over a $>1,000$-fold range in bacterial assays, only HAAs possessing high mutagenic activity or present at great abundance were successfully isolated and characterized from cooked meats, when bacterial mutagenicity assays were employed for screening. 7-MeIgQx, which was initially discovered, by LC/MS, in the urine of meat-eaters 
(11), was not detected in cooked meats by bacterial mutagenesis assays; its mutagenic potency is weak relative to the more mutagenic angular tricyclic HAAs, including 8-MeIQx, which are easily detected in the Ames assay.

Because the known HAAs have been reported to account for $~ 30 \%$ of the total mutagenicity attributed to HAAs in well-done cooked beef, other uncharacterized HAAs are likely present in cooked meat (10). Our characterization of analytes in grilled meats by LC-ESI-MS/MS has clearly shown that other putative HAAs containing the IQx skeleton are present in cooked beef and pan-fried scrapings, and that 7-MeIgQx is the most prominent among these novel HAAs (12). We have also used the highly sensitive YG1024 tester strain to assay the mutagenicity of pan-fried scrapings of beef, following HPLC separation of the HAAs enriched by tandem-SPE (33). Numerous fractions displayed mutagenic activity and many of these fractions were not associated with the $t_{\mathrm{R}}$ of known HAAs (see Supplementary Information, Figure 12). Thus, both the MS analyses and mutagenicity assays provide evidence for the presence of other putative HAAs, of unknown genotoxic potential, in cooked beef.

Although short-term bacterial mutagenesis assays have been an effective screening tool for the identification of some mutagenic HAAs in complex food matrices (34), they cannot reliably predict carcinogenic potency in mammals. For example, the mutagenic potency of $\mathrm{PhIP}$ is about 100-fold lower than the potency of 8-MeIQx, under the same assay conditions (Table 1). However, the two compounds are strong carcinogens and induce tumors at multiple sites in experimental laboratory animals during long-term feeding studies at comparable doses (1, $35,36)$. The newly discovered 7-MeIgQx (348 rev/ $\mu \mathrm{g})$ is approximately 10 -fold lower in mutagenic potency than is PhIP in S. typhimurium strain YG1024 (3,015 rev/ $\mu \mathrm{g})$. It is notable that the potency of 7-MeIgQx is comparable to the potency of 4-aminobiphenyl (4-ABP) in TA98 and YG1024 (frameshift-specific) and YG1029 (primarily point mutation-specific) tester strains (37,38): 4-ABP is a a bladder carcinogen in the experimental dog model and a recognized human urinary bladder carcinogen (39). Two reported studies have directly compared the carcinogenic potencies of 4-ABP and HAAs in rodents. In the neonatal $\mathrm{B} 6 \mathrm{C}_{3} \mathrm{~F}_{1}$ male mouse model, which is highly sensitive to the induction of liver tumors by exposure to chemical carcinogens during a period of rapid liver cell proliferation, the ranking in potency of tumorigenicity, for comparable doses of chemical, was: 4-ABP > Glu-P-1 > IQ $\sim$ PhIP > MeIQx (40). A second study assessed the carcinogenic potencies of IQ and 4-ABP in female Sprague-Dawley rats (41). The two compounds were found to induce tumors of the mammary gland at high frequency and at comparable dose levels. Thus, the potency of a compound in a bacterial mutagenesis assay does not necessarily correlate with carcinogenic potency.

The strong mutagenic potencies of MeIQx and several other HAA of angular tricyclic structure in the S. typhimurium TA98 strain have been attributed to these HAA's ability to frequently induce reversions about 9 base pairs upstream of the original CG deletion in the his $\mathrm{D}^{+}$gene in a run of GC repeats (42): this sequence context may not be a "hot-spot" for PhIP or linear tricyclic HAAs. The weaker mutagenicity of PhIP or 7-MeIgQx relative to 8-MeIQx, is not attributed to the inability of cytochrome P450s to efficiently carry out $N$-oxidation of the exocyclic amine groups (43). On the contrary, the rate of PhIP $N$-oxidation with rat liver microsomes obtained from untreated or PCB-pretreated rats is 5 to 10 -fold greater than the rate of $\mathrm{N}$-oxidation of 8-MeIQx (43). Our preliminary data on the LC-ESI-MS/MS characterization of 7-MeIgQx metabolites produced by rat and human liver microsomes fortified with NADH and NADPH also reveal that both species catalyze the $N$-oxidation of 7-MeI $g$ Qx to the putative, genotoxic $N$-hydroxy metabolite at rates that exceed the $N$-oxidation of 8-MeIQx (R.T., unpublished observations). 
The 16-fold higher mutagenic potency of 7-MeIgQx in the YG1024 bacterial tester strain expressing elevated OAT, relative to this compound's potency in the TA98 strain (Table 1), indicates that the putative $N$-hydroxy-7-MeI $g$ Qx metabolite does undergo $O$-acetylation to form the $N$-acetoxy intermediate, as does 8-MeIQx. A requirement for other phase II enzymes, such as sulfotransferase (which is not expressed at appreciable levels in S. typhimurium TA 98 and YG1024 strains) may be necessary for the efficient bioactivation of $N$-hydroxy-7$\mathrm{MeI} g \mathrm{Qx}$, as has been reported for PhIP and MeA $\alpha \mathrm{C}(44,45)$. Given the elevated concentrations of 7-MeIgQx, as compared to many other known, carcinogenic HAAs formed in cooked ground beef, further studies on the genetic damage and health risk of this novel HAA are clearly warranted.

\section{Supplementary Material}

Refer to Web version on PubMed Central for supplementary material.

\section{Acknowledgements}

This research is funded in part by the Wadsworth Center, New York State Department of Health, and supported by grant number 05B025 from the American Institute for Cancer Research, and done in part under the auspices of the U.S. Department of Energy by Lawrence Livermore National Laboratory under contract W-7405-ENG-48 and funded in part by NCI grant CA55861. We acknowledge the assistance of the NMR Structural Biology Facility at the Wadsworth Center. We thank Drs. C. Rizzo, C. E. Elmquist, and J. Stover, Vanderbilt University, for their helpful dicussions on syntheses. Disclaimer: The views presented in this article do not necessarily represent those of the United States Food and Drug Administration.

\section{References}

1. Sugimura T, Wakabayashi K, Nakagama H, Nagao M. Heterocyclic amines: Mutagens/carcinogens produced during cooking of meat and fish. Cancer Sci 2004;95:290-299. [PubMed: 15072585]

2. Felton, JS.; Jagerstad, M.; Knize, MG.; Skog, K.; Wakabayashi, K. Contents in Foods, Beverages and Tobacco. In: Nagao, M.; Sugimura, T., editors. Food Borne Carcinogens Heterocyclic Amines. John Wiley \& Sons Ltd.; Chichester, England: 2000. p. 31-71.

3. Cross AJ, Sinha R. Meat-related mutagens/carcinogens in the etiology of colorectal cancer. Environ Mol Mutagen 2004;44:44-55. [PubMed: 15199546]

4. Lang NP, Butler MA, Massengill JP, Lawson M, Stotts RC, Hauer-Jensen M, Kadlubar FF. Rapid metabolic phenotypes for acetyltransferase and cytochrome P4501A2 and putative exposure to foodborne heterocyclic amines increase the risk for colorectal cancer or polyps. Cancer Epidemiol Biomarkers Prev 1994;3:675-682. [PubMed: 7881341]

5. Le Marchand L, Hankin JH, Wilkens LR, Pierce LM, Franke A, Kolonel LN, Seifried A, Custer LJ, Chang W, Lum-Jones A, Donlon T. Combined effects of well-done red meat, smoking, and rapid Nacetyltransferase 2 and CYP1A2 phenotypes in increasing colorectal cancer risk. Cancer Epidemiol Biomarkers Prev 2001;10:1259-1266. [PubMed: 11751443]

6. Friesen MD, Kaderlik K, Lin D, Garren L, Bartsch H, Lang NP, Kadlubar FF. Analysis of DNA adducts of 2-amino-1-methyl-6-phenylimidazo[4,5- $b$ ]pyridine in rat and human tissues by alkaline hydrolysis and gas chromatography/electron capture mass spectrometry: validation by comparison with ${ }^{32} \mathrm{P}-$ postlabeling. Chem Res Toxicol 1994;7:733-739. [PubMed: 7696526]

7. Totsuka Y, Fukutome K, Takahashi M, Takashi S, Tada A, Sugimura T, Wakabayashi K. Presence of $N^{2}$-(deoxyguanosin-8-yl)-2-amino-3,8-dimethylimidazo[4,5-f]quinoxaline (dG-C8-MeIQx) in human tissues. Carcinogenesis 1996;17:1029-1034. [PubMed: 8640908]

8. Zhu J, Chang P, Bondy ML, Sahin AA, Singletary SE, Takahashi S, Shirai T, Li D. Detection of 2amino-1-methyl-6-phenylimidazo[4,5-b]-pyridine-DNA adducts in normal breast tissues and risk of breast cancer. Cancer Epidemiol Biomarkers Prev 2003;12:830-837. [PubMed: 14504191]

9. Magagnotti C, Pastorelli R, Pozzi S, Andreoni B, Fanelli R, Airoldi L. Genetic polymorphisms and modulation of 2-amino-1-methyl-6-phenylimidazo[4,5-b]pyridine (PhIP)-DNA adducts in human lymphocytes. Int J Cancer 2003;107:878-884. [PubMed: 14601045] 
10. Knize MG, Dolbeare FA, Carroll KL, Moore DH, Felton JS. Effect of cooking time and temperature on the heterocyclic amine content of fried beef patties. Food Chem Toxicol 1994;32:595-603. [PubMed: 8045472]

11. Holland RD, Taylor J, Schoenbachler L, Jones RC, Freeman JP, Miller DW, Lake BG, Gooderham NJ, Turesky RJ. Rapid biomonitoring of heterocyclic aromatic amines in human urine by tandem solvent solid phase extraction liquid chromatography electrospray ionization mass spectrometry. Chem Res Toxicol 2004;17:1121-1136. [PubMed: 15310244]

12. Turesky RJ, Taylor J, Schnackenberg L, Freeman JP, Holland RD. Quantitation of carcinogenic heterocyclic aromatic amines and detection of novel heterocyclic aromatic amines in cooked meats and grill scrapings by HPLC/ESI-MS. J Agric Food Chem 2005;53:3248-3258. [PubMed: 15826085]

13. Turesky RJ, Bur H, Huynh-Ba T, Aeschbacher HU, Milon H. Analysis of mutagenic heterocyclic amines in cooked beef products by high-performance liquid chromatography in combination with mass spectrometry. Food Chem Toxicol 1988;26:501-509. [PubMed: 3169649]

14. Ronne E, Olsson K, Grivas S. One-step synthesis of 2-amino-1-methylimidazo[4,5-b]quinoline. Synthetic Commun 1994;24:1363-1366.

15. Neilson T, Wood HCS, Wylie AG. Reduction of aromatic nitro-compounds by sodium borohydride catalyzed by palladised charcoal. J Chem Soc 1962:371-372.

16. Yamaizumi Z, Kasai H, Nishimura S, Edmonds CG, McCloskey JA. Stable isotope dilution quantification of mutagens in cooked foods by combined liquid chromatography-thermospray mass spectrometry. Mutat Res 1986;173:1-7. [PubMed: 3941675]

17. Gross GA, Gruter A. Quantitation of mutagenic/carcinogenic heterocyclic aromatic amines in food products. J Chromatogr 1992;592:271-278. [PubMed: 1583097]

18. Holder CL, Preece SW, Conway SC, Pu YM, Doerge DR. Quantification of heterocyclic amine carcinogens in cooked meats using isotope dilution liquid chromatography/atmospheric pressure chemical ionization tandem mass spectrometry. Rapid Commun Mass Spectrom 1997;11:16671672. [PubMed: 9364795]

19. Guy PA, Gremaud E, Richoz J, Turesky RJ. Quantitative analysis of mutagenic heterocyclic aromatic amines in cooked meat using liquid chromatography-atmospheric pressure chemical ionisation tandem mass spectrometry. J Chromatogr A 2000;883:89-102. [PubMed: 10910203]

20. Toribio F, Moyano E, Puignou L, Galceran MT. Multistep mass spectrometry of heterocyclic amines in a quadrupole ion trap mass analyser. J Mass Spectrom 2002;37:812-828. [PubMed: 12203675]

21. Maron DM, Ames BN. Revised methods for the Salmonella mutagenicity test. Mutat Res 1983;113:173-215. [PubMed: 6341825]

22. Malfatti MA, Shen NH, Wu RW, Turteltaub KW, Felton JS. A correlation of Salmonella mutagenicity with DNA adducts induced by the cooked-food mutagen 2-amino-1-methyl-6-phenylimidazo[4,5-b] pyridine. Mutagenesis 1995;10:425-431. [PubMed: 8544756]

23. Grivas, S. Synthetic routes to the food carcinogen 2 amino-3,8-dimethylimidazo[4,5-f]quinoxaline (8-MeIQx) and related compounds. In: Adamson, RH.; Gusatfsson, JA.; Ito, N.; Nagao, M.; Sugimura, T.; Wakabayashi, K.; Yamazoe, Y., editors. Heterocyclic aromatic amines: Possible Human Carcinogens. Proceedings of the 23rd International Princess Takamatsu Symposium; Princeton: Princeton Scientific Publishing Co., Inc.; 1995. p. 1-8.

24. Wu YQ, Wilkinson DE, Hamilton GS. Formation of nitrogen-containing heterocycles using di (imidazole-1-yl)methanimine. J Heterocycl Chem 2003;40:191-193.

25. Tanga MJ, Bupp JE, Tochimoto TK. Syntheses of 1,5,6-trimethyl-2-aminoimidazo[4,5- $b$ ]pyridine and 3,5,6-trimethyl-2-aminoimidazo[4,5- $b$ ]pyridine. J Heterocycl Chem 1994;31:1641-1645.

26. Knize MG, Felton JS. The synthesis of the cooked-beef mutagen 2-amino-1-methyl-6-phenylimidazo [4,5-b]pyridine and its 3-methyl isomer. Heterocycles 1986;24:1815-1819.

27. Nukaya H, Koyota S, Jinno F, Ishida H, Wakabayashi K, Kurosaka R, Kim IS, Yamaizumi Z, Ushiyama H, Sugimura T. Structural determination of a new mutagenic heterocyclic amine, 2amino-1,7,9-trimethylimidazo[4,5-g]quinoxaline (7,9-DiMeIgQx), present in beef extract. Carcinogenesis 1994;15:1151-1154. [PubMed: 8020148]

28. Einisto P, Watanabe M, Ishidate M Jr, Nohmi T. Mutagenicity of 30 chemicals in Salmonella typhimurium strains possessing different nitroreductase or O-acetyltransferase activities. Mutat Res 1991;259:95-102. [PubMed: 1988826] 
29. Watanabe M, Ishidate M Jr, Nohmi T. Sensitive method for the detection of mutagenic nitroarenes and aromatic amines: new derivatives of Salmonella typhimurium tester strains possessing elevated O-acetyltransferase levels. Mutat Res 1990;234:337-348. [PubMed: 2215547]

30. Felton JS, Knize MG, Shen NH, Andresen BD, Bjeldanes LF, Hatch FT. Identification of the mutagens in cooked beef. Environ Health Perspect 1986;67:17-24. [PubMed: 3757953]

31. Pais P, Knize MG. Chromatographic and related techniques for the determination of aromatic heterocyclic amines in foods. J Chromatogr B 2000;747:139-169.

32. Wakabayashi, K.; Kim, IS.; Kurosaka, R.; Yamaizumi, Z.; Ushiyama, H.; Takahashi, M.; Koyota, S.; Tada, A.; Nukaya, H.; Goto, S. Identification of new mutagenic heterocyclic amines and quantification of known heterocyclic amines. In: Adamson, RH.; Gustafson, DR.; Ito, N.; Nagao, M.; Sugimura, T.; Wakabayashi, K.; Yamazoe, Y., editors. Heterocyclic aromatic amines: Possible Human Carcinogens. Proceedings of the 23rd International Princess Takamatsu Symposium; Princeton: Princeton Scientific Publishing Co., Inc.; 1995. p. 39-49.

33. Knize MG, Felton JS, Gross GA. Chromatographic methods for the analysis of heterocyclic amine food mutagens/carcinogens. J Chromatogr 1992;624:253-265. [PubMed: 1494008]

34. Sugimura T. Successful use of short-term tests for academic purposes: Their use in identification of new environmental carcinogens with possible risk for humans. Mutat Res 1988;205:33-39. [PubMed: 3367922]

35. Sugimura T, Nagao M, Wakabayashi K. Carcinogenicity of food mutagens. Environ Health Persp 1996;104:429-433.

36. Sugimura T. Overview of carcinogenic heterocyclic amines. Mutat Res 1997;376:211-219. [PubMed: 9202758]

37. Scribner JD, Fisk SR, Scribner NK. Mechanisms of action of carcinogenic aromatic amines: an investigation using mutagenesis in bacteria. Chem Biol Interact 1979;26:11-25. [PubMed: 380829]

38. Thompson PA, DeMarini DM, Kadlubar FF, McClure GY, Brooks LR, Green BL, Fares MY, Stone A, Josephy PD, Ambrosone CB. Evidence for the presence of mutagenic arylamines in human breast milk and DNA adducts in exfoliated breast ductal epithelial cells. Environ Mol Mutagen 2002;39:134-142. [PubMed: 11921181]

39. Kadlubar, FF.; Beland, FA. Chemical properties of ultimate carcinogenic metabolites of arylamines and arylamides. In: Harvey, RG., editor. Polycyclic Hydrocarbons and Carcinogenesis. American Chemical Society; Washington, D.C.: 1985. p. 332-370.

40. Dooley KL, Von Tungelin LS, Bucci T, Kadlubar FF. Comparative carcinogenicity of 4aminobiphenyl and the food pyrolysates, Glu-P-1, IQ, PhIP, and MeIQx in the neonatal B6C $3 \mathrm{~F}_{1}$ male mouse. Cancer Lett 1992;62:205-209. [PubMed: 1596864]

41. Tanaka T, Barnes WS, Williams GM, Weisburger JH. Multipotential carcinogenicity of the fried food mutagen 2-amino-3-methylimidazo[4,5-f]quinoline in rats. Jpn J Cancer Res 1985;76:570-576. [PubMed: 3928552]

42. Fuscoe JC, Wu R, Shen NH, Healy SK, Felton JS. Base-change analysis of revertants of the hisD3052 allele in Salmonella typhimurium. Mutat Res 1988;201:241-251. [PubMed: 3138534]

43. Turesky RJ, Constable A, Richoz J, Varga N, Markovic J, Martin MV, Guengerich FP. Activation of heterocyclic aromatic amines by rat and human liver microsomes and by purified rat and human cytochrome P450 1A2. Chem Res Toxicol 1998;11:925-936. [PubMed: 9705755]

44. Wu RW, Panteleakos FN, Kadkhodayan S, Bolton-Grob R, McManus ME, Felton JS. Genetically modified Chinese hamster ovary cells for investigating sulfotransferase-mediated cytotoxicity and mutation by 2-amino-1-methyl-6- phenylimidazo[4,5-b]pyridine. Environ Mol Mutagen 2000;35:57-65. [PubMed: 10692228]

45. Glatt H, Pabel U, Meinl W, Frederiksen H, Frandsen H, Muckel E. Bioactivation of the heterocyclic aromatic amine 2-amino-3-methyl-9H-pyrido [2,3-b]indole (MeAalphaC) in recombinant test systems expressing human xenobiotic-metabolizing enzymes. Carcinogenesis 2004;25:801-807. [PubMed: 14729582]

\section{Abbreviations}

\section{4-ABP}




\author{
4-aminobiphenyl \\ 4-MeIQx \\ 2-amino-3,4-dimethylimidazo[4,5-f]quinoxaline \\ 6-MeIQx \\ 2-amino-3,6-dimethylimidazo[4,5-f]quinoxaline \\ 7-MeIQx \\ 2-amino-3,7-dimethylimidazo[4,5-f]quinoxaline \\ 8-MeIQx \\ 2-amino-3,8-dimethylimidazo[4,5-f]quinoxaline \\ 6-MeIgQx \\ 2-amino-1,6-dimethylimidazo[4,5-g]quinoxaline \\ 7-MeIgQx \\ 2-amino-1,7-dimethylimidazo[4,5-g]quinoxaline
}

Glu-P-1

2-amino-6-methyldipyrido[1,2-a:3',2'-d]imidazole

IQx

2-amino-3-methylimidazo[4,5-f]quinoxaline

$\mathrm{IQ}[4,5-b]$

2-amino-1-methylimidazo[4,5-b]quinoline

IQ

2-amino-3-methylimidazo[4,5-f]quinoline

PhIP

2-amino-1-methyl-6-phenylimidazo[4,5- $b]$ pyridine

$\mathrm{A \alpha C}$

2-amino-9H-pyrido[2,3-b]indole

MeAaC

2-amino-3-methyl-9H-pyrido[2,3-b]indole

4,8-DiMeIQx

2-amino-3,4,8-trimethylimidazo[4,5-f]quinoxaline

7,8-DiMeIQx

2-amino-3,7,8-trimethylimidazo[4,5-f]quinoxaline

7,9-DiMeIgQx

2-amino-1,7,9-trimethylimidazo[4,5-g]quinoxaline

CID

collision induced dissociation

HAA

heterocyclic aromatic amine

\title{
LC-ESI-MS/MS
}

liquid chromatography-electrospray ionization tandem mass spectrometry

Chem Res Toxicol. Author manuscript; available in PMC 2008 September 10. 
MS

mass spectrometry

OAT

$O$-acetyltransferase

ppb

parts-per-billion

PCBs

polychlorinated biphenyls

SRM

selected reaction monitoring

SPE

solid phase extraction

TSQ

Finnigan $^{\mathrm{TM}}$ TSQ Quantum Ultra ${ }^{\mathrm{TM}}$ triple quadrupole mass spectrometer

\section{HMBC and ROESY refer to commonly used pulse programs}

HMBC experiments create two-dimensional NMR spectra that correlate the signals of neighboring protons with neighboring carbon atoms, and ROESY experiments establish the spatial proximity between protons 
<smiles>Cn1c(N)nc2c3cccnc3ccc21</smiles><smiles></smiles><smiles>[R]c1nc2cc([R])c3c(nc(N)n3C)c2nc1[R]</smiles>

$\mathrm{R}_{1}, \mathrm{R}_{2}, \mathrm{R}_{3}=\mathrm{H}(\mathrm{IQx})$

$\mathrm{R}_{1}=\mathrm{CH}_{3} ; \mathrm{R}_{2}, \mathrm{R}_{3}=\mathrm{H}$ (4-MelQx)

$\mathrm{R}_{1}, \mathrm{R}_{3}=\mathrm{H} ; \mathrm{R}_{2}=\mathrm{CH}_{3}(\mathbf{7}-\mathrm{MelQx})$

$\mathrm{R}_{1}, \mathrm{R}_{2}=\mathrm{H} ; \mathrm{R}_{3}=\mathrm{CH}_{3}$ (8-MelQx)

$\mathrm{R}_{1}, \mathrm{R}_{3}=\mathrm{CH}_{3} ; \mathrm{R}_{2}=\mathrm{H}(\mathbf{4}, 8-$ DiMelQx $)$<smiles>Cn1c(N)nc2ccc(-c3ccccc3)cc21</smiles>

PhIP<smiles>[R]c1cc2c(nc1N)[nH]c1ccccc12</smiles>

$\mathrm{R}_{1}=\mathrm{H}(\mathbf{A \alpha C})$

$\mathrm{R}_{1}=\mathrm{CH}_{3}(\mathrm{MeA \alpha C})$

Figure 1.

Chemical structures of HAAs investigated in this study. 

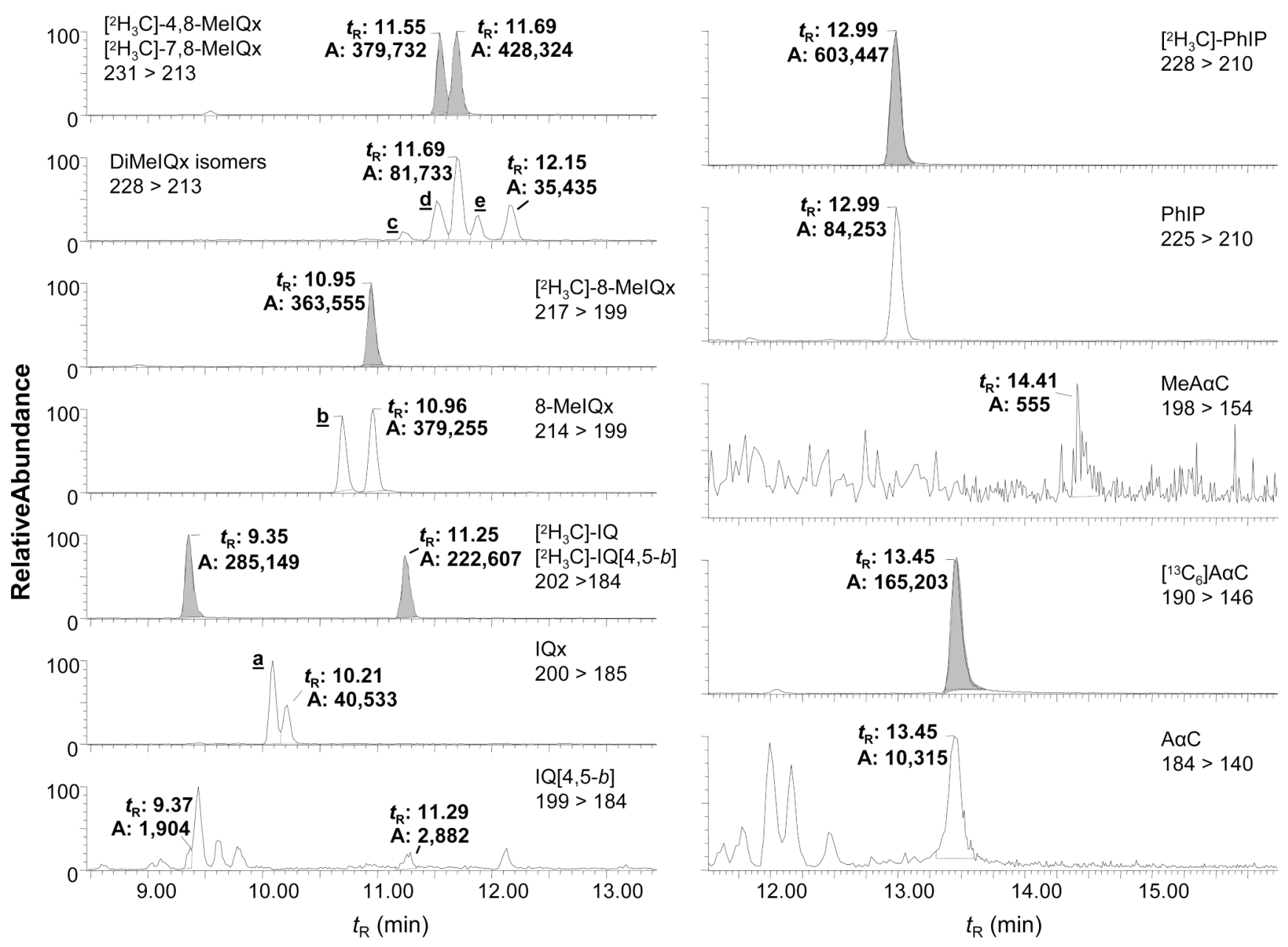

Figure 2.

LC-ESI-MS/MS analyses of HAAs formed in ground beef patties fried at $165^{\circ} \mathrm{C}$ for $10 \mathrm{~min} /$ side. Peaks labeled a - e represent novel HAAs, based upon the product ion spectra, which show the presence of either an IQx or I $g$ Qx skeleton (12). The HAAs and respective $t_{\mathrm{R}}(\mathrm{min})$ are: IQ (9.37), IQx (10.21), 8-MeIQx (10.96), IQ[4,5-b] (11.29), 7,8-DiMeIQx (11.55), 4,8DiMeIQx (11.69), 7,9-DiMeIgQx (12.15), PhIP (12.99), A $\alpha \mathrm{C}$ (13.45), MeA $\alpha \mathrm{C}$ (14.4). Internal standards are shaded in gray. Peak d contains two HAAs: 7,8-DiMeIQx and another putative DiMeIQx (12). 


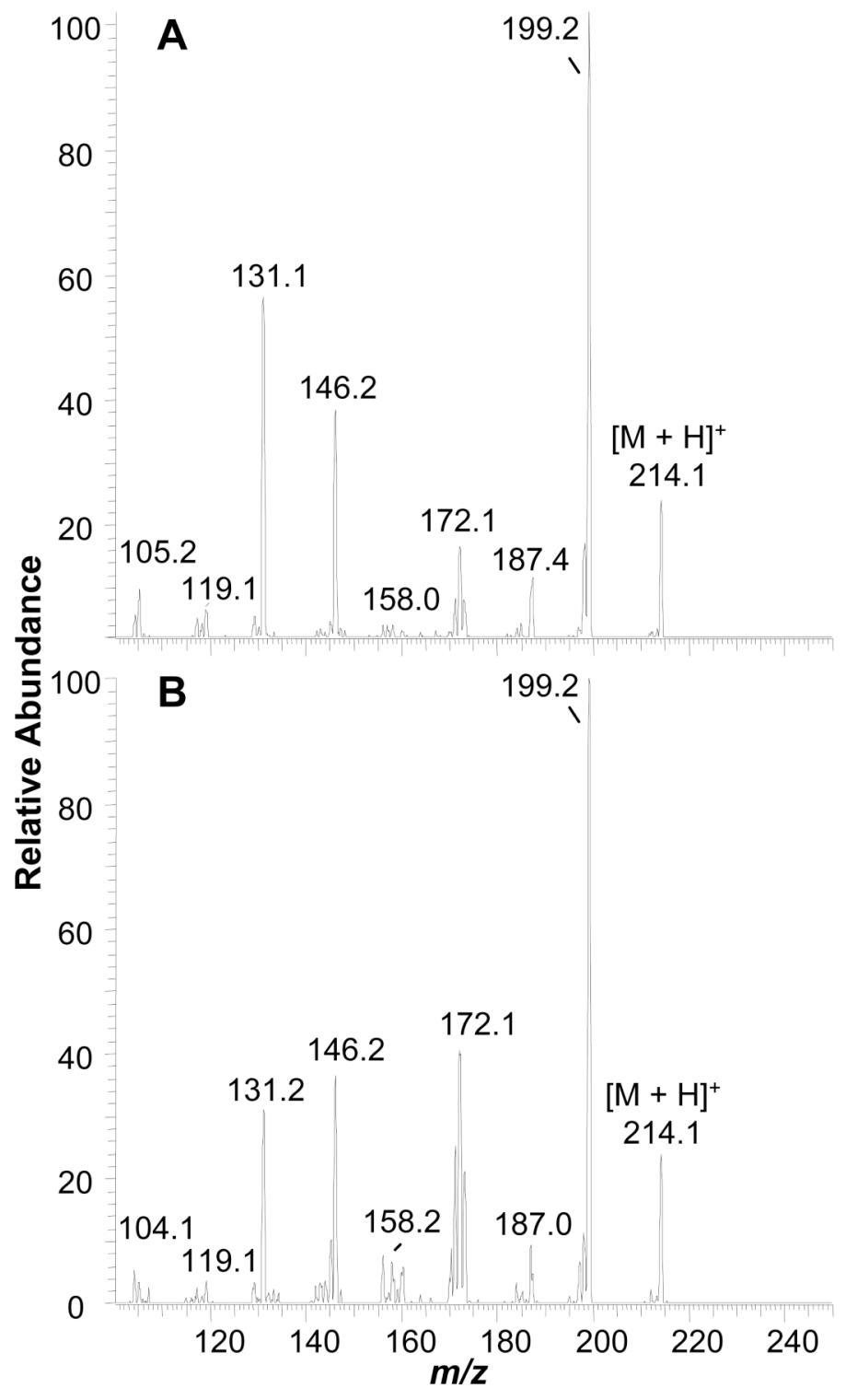

Figure 3.

LC-ESI-MS/MS product ion spectra of (A) novel 7-MeIgQx isomer and (B) 8-MeIQx formed in cooked beef. 

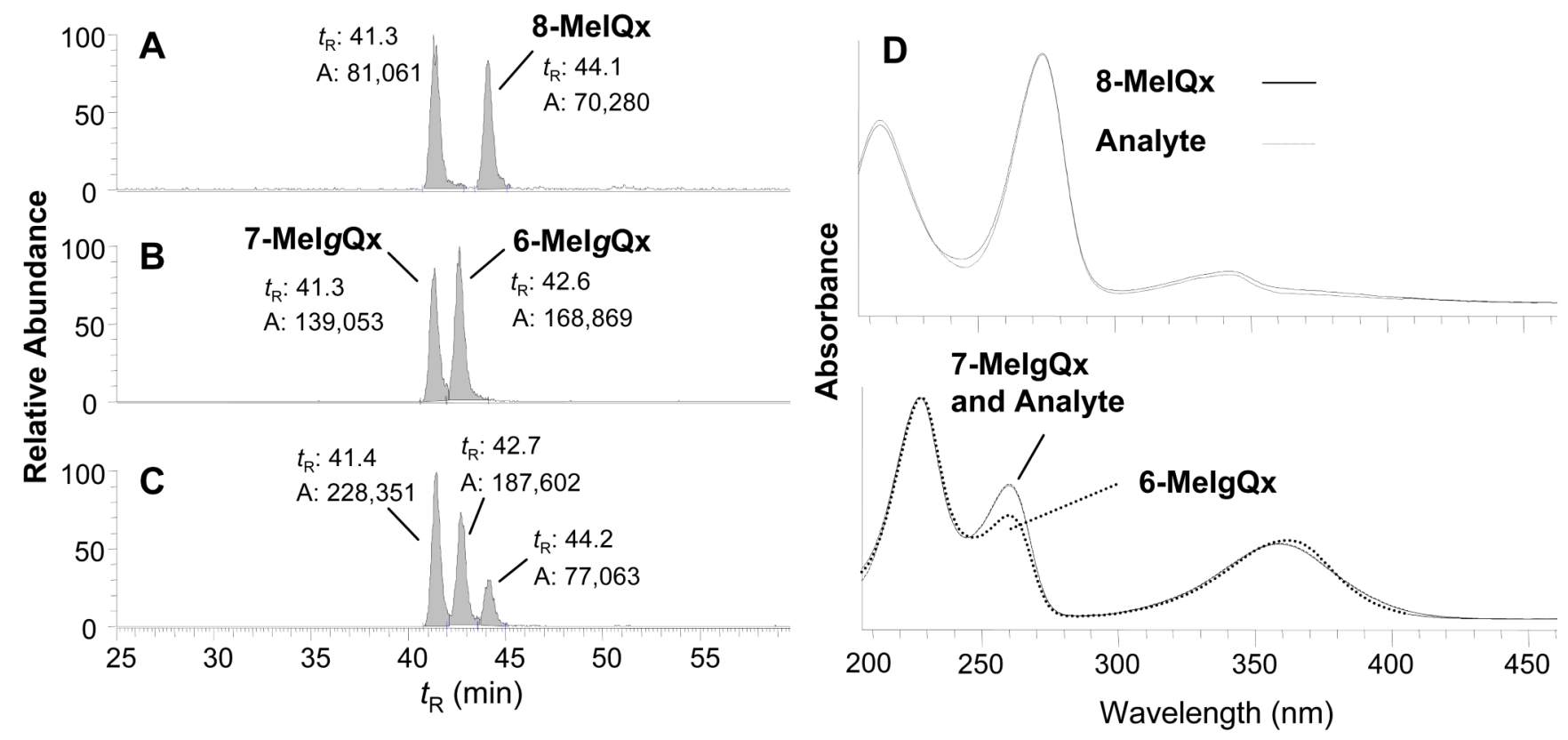

Figure 4.

HPLC-ESI-MS/MS and UV spectral characterization of 8-MeIQx and MeIgQx isomers formed in cooked beef. (A) Unspiked pan-fried meat scrapings (upper panel), (B) synthetic 6- and 7MeIgQx isomers (1500 pg), and (C) pan-fried meat scrapings spiked with $1500 \mathrm{pg}$ of 6- and 7-MeIgQx. HPLC separation of the MeIQx isomers was done with HPLC System 1. The effluent was split 1:10 post-column prior to entering the MS source. (D) On-line HPLC UV spectra of synthetic HAAs and analytes isolated from pan-fried meat scrapings. The UV spectra of synthetic isomers are superimposed with the analytes. The 8-MeIQx and analyte (dashed line) are indistinguishable. The chromophores of 7-MeIgQx and the analyte are nearly identical, while the 6-MeIgQx isomer (dotted trace) displays a less intense maximum at 260 $\mathrm{nm}$ and a $3 \mathrm{~nm}$ bathochromic shift, relative to 7-MeI $g$ Qx, at $363 \mathrm{~nm}$. 


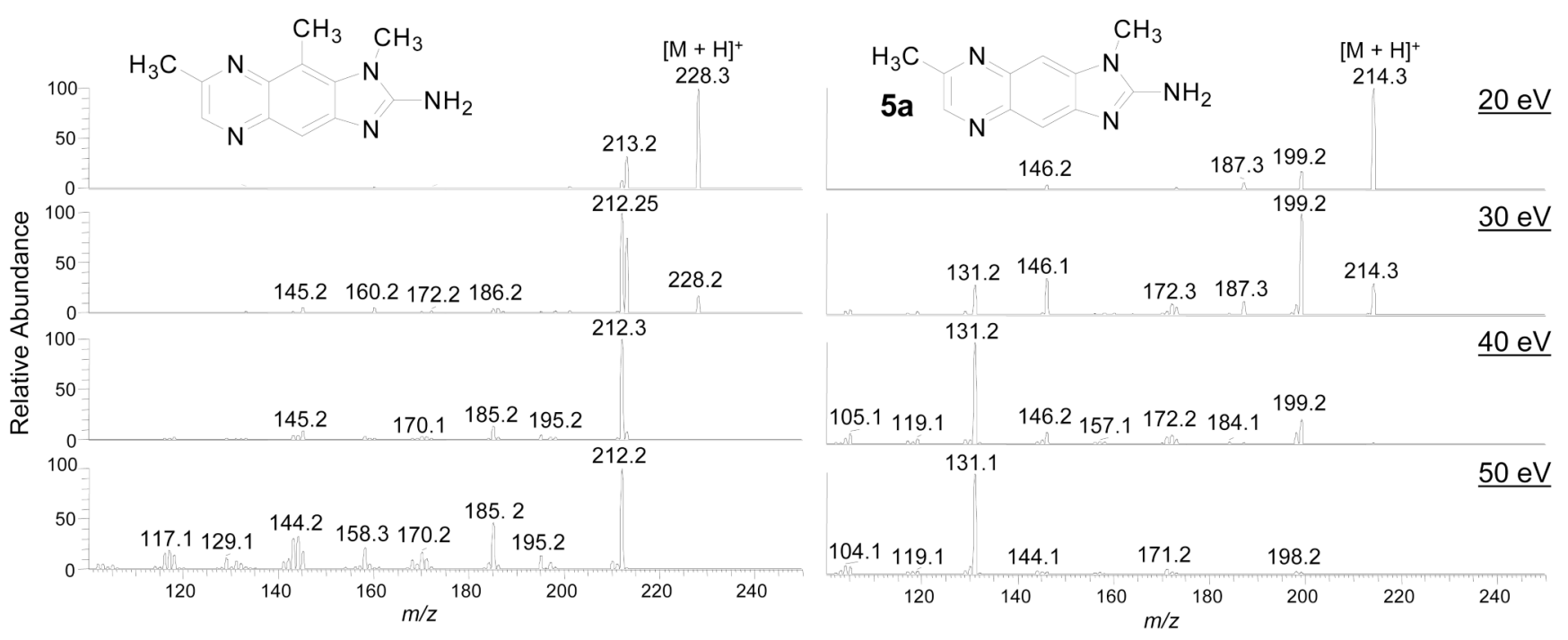

Figure 5.

LC-ESI-MS/MS product ion spectra of 7-MeIgQx and 7,9-DiMeIgQx at several different collision energies. 

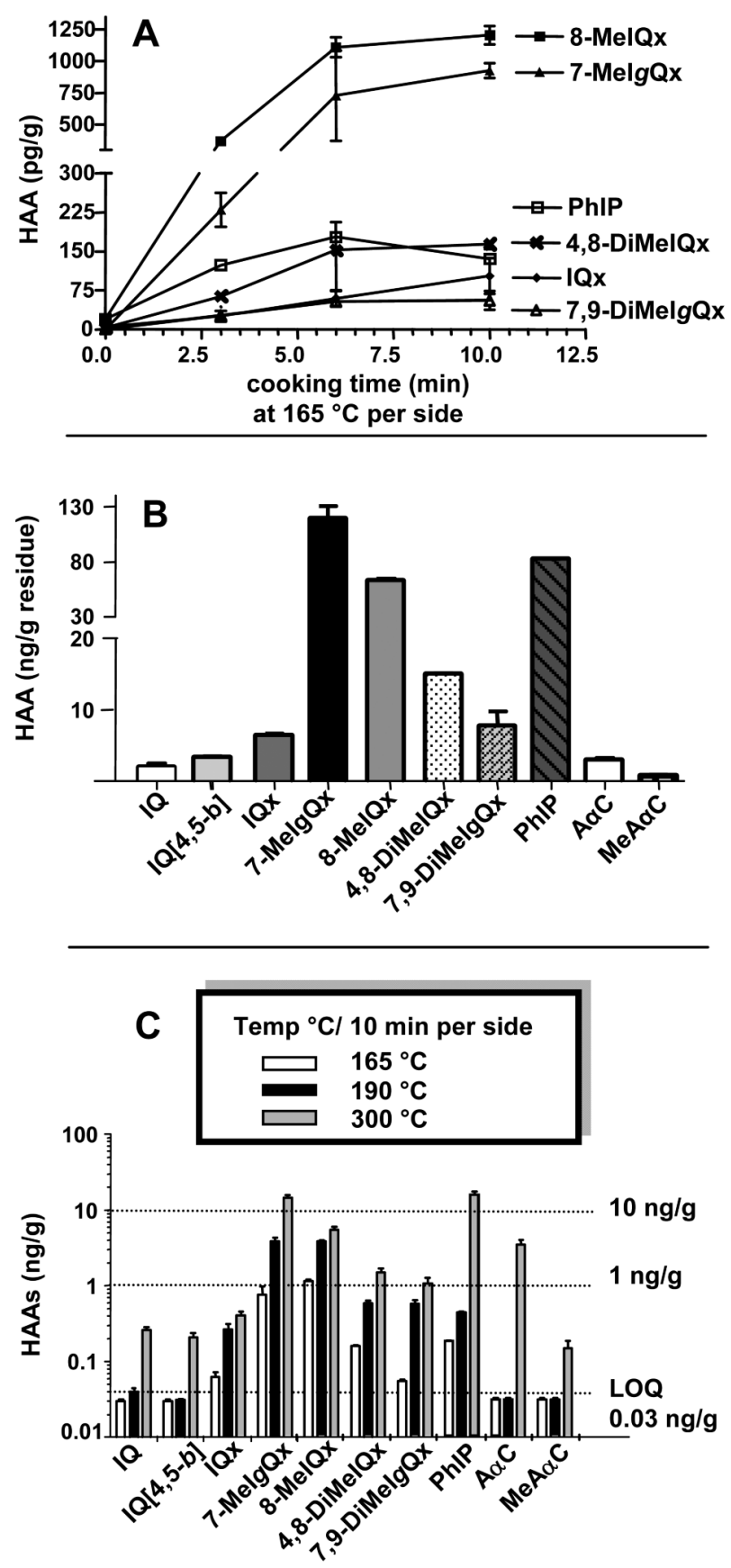

Figure 6.

Formation of 7-MeIgQx and other HAAs in grilled ground beef patties. (A) HAA formation as a function of cooking time; (B) HAA content in grilled meat scrapings from ground beef cooked at $165{ }^{\circ} \mathrm{C}$ for $10 \mathrm{~min}$; and (C) HAA formation in grilled beef patties as a function of temperature. The limit of quantification (LOQ) was $0.03 \mathrm{ppb}$. 

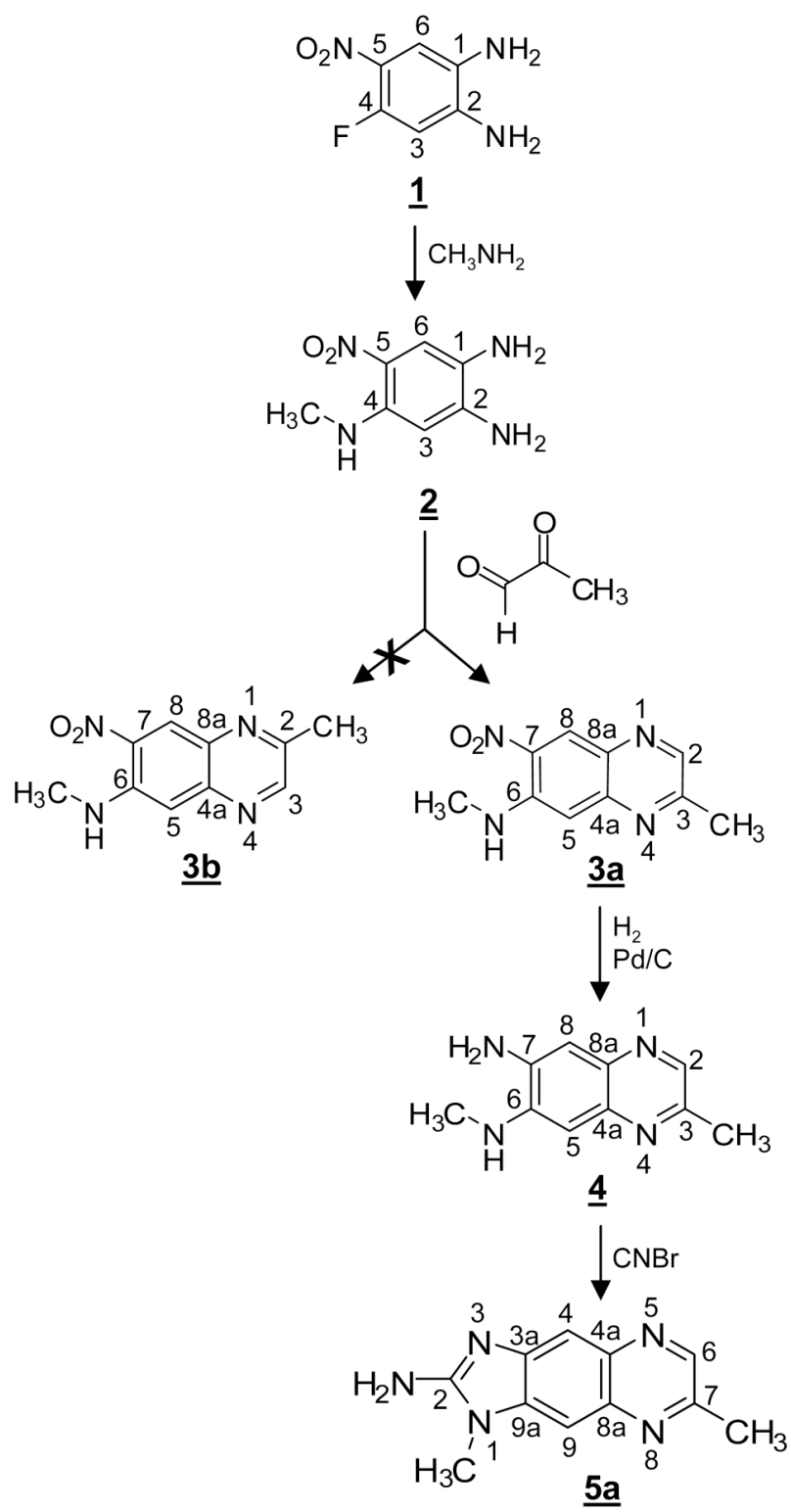

Scheme 1.

Regioselective synthesis of 7-MeIgQx. 


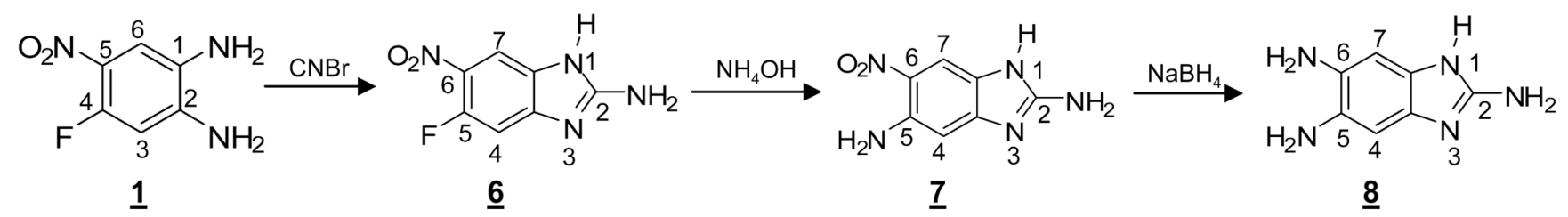

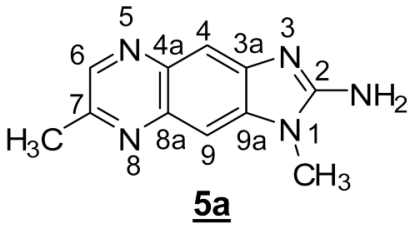

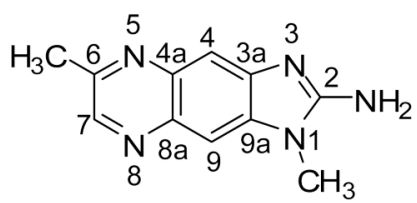

$\underline{5 b}$

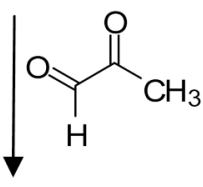

$\stackrel{\mathrm{CH}_{3} \mathrm{I}}{\longleftarrow}$

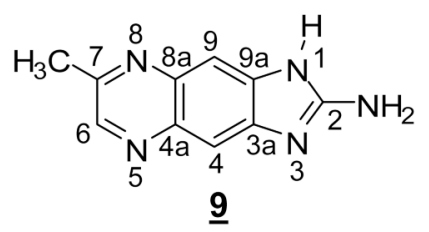

Scheme 2.

Alternative synthesis of 6-MeIgQx and 7-MeIgQx. 
<smiles>Cc1cnc2cc3nc(N)n(C)c3c(C)c2n1</smiles>

$m / z 228$

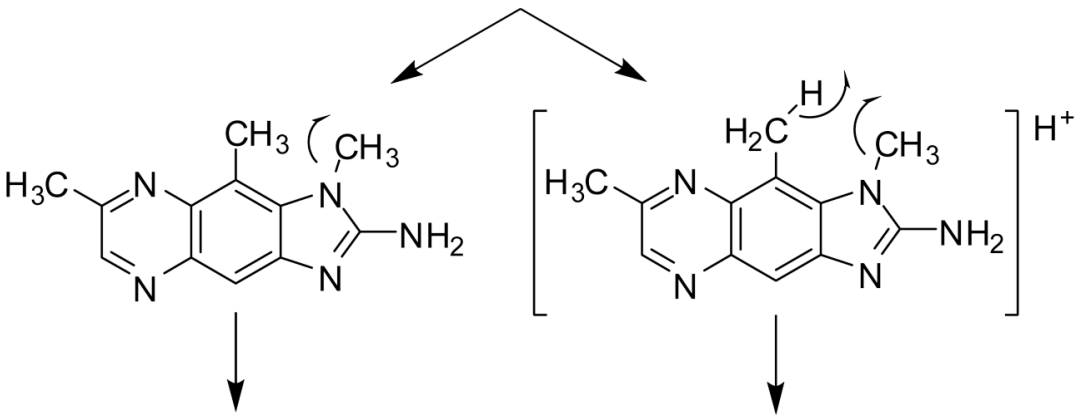<smiles></smiles>

$m / z 213$<smiles>C=c1c2c(cc3ncc(C)nc13)N=C(N)N=2</smiles>

$m / z 212$

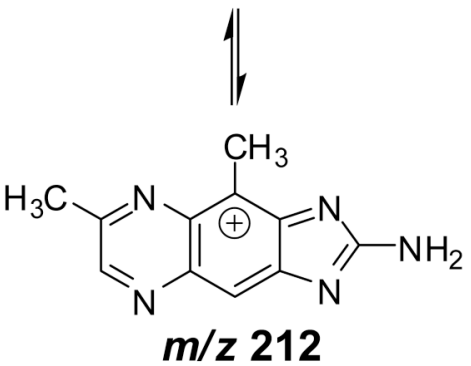<smiles></smiles><smiles>C[C@H]1C[C@H]2CC[C@H]1C2</smiles>

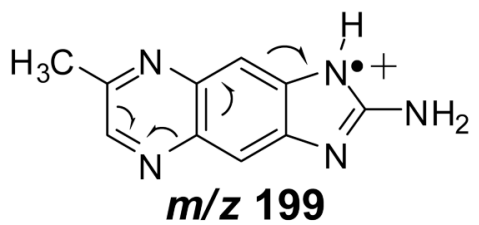

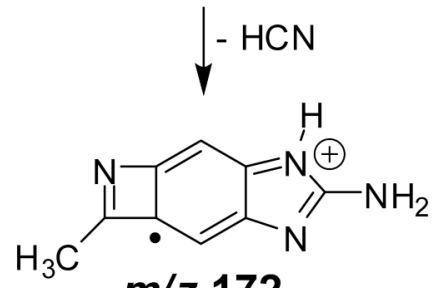

$m / z 172$

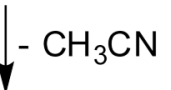<smiles>NC1=NC2=C[CH+]C=CC2=N1</smiles>

$\mathrm{m} / \mathrm{z} 131$

Scheme 3.

Proposed mechanisms of mass fragmentation of 7-MeIgQx and 7,9-DiMeI $g$ Qx under LC-ESIMS/MS conditions. 
Table 1

Mutagenic Potencies of HAAs in S. typhiumurium TA98 and YG1024 Tester Strains

\begin{tabular}{|c|c|c|c|}
\hline \multirow{2}{*}{ Compound } & \multicolumn{2}{|c|}{ Revertants/ug } & \multicolumn{2}{c|}{ Response Ratio } \\
\cline { 2 - 4 } & TA98 & YG1024 & YG1024 / TA98 \\
\hline 6-MeIgQx & 6 & 46 & 7.7 \\
\hline 7-MeIgQx & 22 & 348 & 15.8 \\
\hline 7.9-DiMeIgOx & 638 & 2.420 & 3.8 \\
\hline PhIP & 931 & 3.110 & 3.3 \\
\hline 8-MeIQx & 117,000 & $1,400,000$ & 12.0 \\
\hline
\end{tabular}

